\title{
Shoreline changes and high-energy wave impacts at the leeward coast of Bonaire (Netherlands Antilles)
}

\author{
Max Engel ${ }^{1}$, Helmut Brückner ${ }^{1}$, Karoline Messenzehl ${ }^{2}$, Peter Frenzel ${ }^{3}$, Simon Matthias May ${ }^{1}$, Anja Scheffers ${ }^{4}$, \\ Sander Scheffers ${ }^{5}$, Volker Wennrich ${ }^{6}$, and Dieter Kelletat ${ }^{1}$ \\ ${ }^{1}$ Institute of Geography, Universität zu Köln, Albertus-Magnus-Platz, 50923 Cologne, Germany \\ ${ }^{2}$ Department of Geography, Rheinische Friedrich-Wilhelms-Universität Bonn, Meckenheimer Allee 166, 53115 Bonn, Germany \\ ${ }^{3}$ Institute of Earth Sciences, Friedrich-Schiller-Universität Jena, Burgweg 11, 07749 Jena, Germany \\ ${ }^{4}$ Southern Cross GeoScience, Southern Cross University, PO Box 157, Lismore NSW 2480, Australia \\ ${ }^{5}$ Marine Ecology Research Centre, Southern Cross University, PO Box 157, Lismore NSW 2480, Australia \\ ${ }^{6}$ Institute of Geology and Mineralogy, Universität zu Köln, Albertus-Magnus-Platz, 50923 Cologne, Germany
}

(Received December 7, 2010; Revised July 11, 2011; Accepted August 9, 2011; Online published October 24, 2012)

\begin{abstract}
Supralittoral coarse-clast deposits along the shores of Bonaire (Netherlands Antilles) as well as increased hurricane frequency during the past decade testify to the major hazard of high-energy wave impacts in the southern Caribbean. Since deducing certain events from the subaerial coarse-clast record involves major uncertainties and historical reports are restricted to the past 500 years, we use a new set of vibracore and push core data (i) to contribute to a more reliable Holocene history of regional extreme-wave events and (ii) to evaluate their impact on shoreline evolution. Multi-proxy palaeoenvironmental analyses (XRF, XRD, grain size distribution, carbonate, LOI, microfossils) were carried out using nearshore sedimentary archives from the sheltered western (leeward) side of Bonaire and its small neighbour Klein Bonaire. In combination with ${ }^{14} \mathrm{C}$-AMS age estimates the stratigraphy reflects a long-term coastal evolution controlled by relative sea level rise, longshore sediment transport, and short-term morphodynamic impulses by extreme wave action, all three of which may have significantly influenced the development of polyhaline lagoons and the demise of mangrove populations. Extreme wave events may be categorized into major episodic incidents (c. $3.6 \mathrm{ka}$ [?] BP; 3.2-3.0 ka BP; 2.0-1.8 ka BP; post-1.3 ka [?] $\mathrm{BP}$ ), which may correspond to tsunamis and periodic events recurring on the order of decades to centuries, which we interpret as severe tropical cyclones. Extreme wave events seem to control to a certain extent the formation of coastal ridges on Bonaire and, thus, to cause abrupt shifts in the long-term morphodynamic and ecological boundary conditions of the circumlittoral inland bays.
\end{abstract}

Key words: Washover deposits, tropical cyclones (hurricanes), tsunamis, Holocene stratigraphy, coastal hazards, environmental change, Caribbean.

\section{Introduction}

A broad spectrum of potential triggering mechanisms of tsunamis exists throughout the Caribbean region. These include (i) earthquake-triggering tectonic movement (strikeslip motion, oblique convergence) along the boundary of the Caribbean and North American Plates (Grindlay et al., 2005) or the Venezuelan coast (Audemard et al., 2005); (ii) the Lesser Antilles subduction zone with earthquakes and various sources of explosive and effusive volcanism (e.g. Zahibo and Pelinovsky, 2001; Mattioli et al., 2007); (iii) morphological signatures of large-scale submarine mass failure, e.g. north of Puerto Rico (Grindlay et al., 2005; ten Brink et al., 2006) or on Curaçao (Hornbach et al., 2010); (iv) submarine debris avalanches along the Lesser Antilles arc (Deplus et al., 2001); (v) teletsunamis from the open Atlantic Ocean as triggered by the 1755 Lisbon earthquake (O'Loughlin and Lander, 2003) or by a future vol-

Copyright (C) The Society of Geomagnetism and Earth, Planetary and Space Sciences (SGEPSS); The Seismological Society of Japan; The Volcanological Society of Japan; The Geodetic Society of Japan; The Japanese Society for Planetary Sciences; TERRAPUB.

doi:10.5047/eps.2011.08.011 canic edifice collapse at the Canary Islands (Ward and Day, 2001). In some places possible geologic evidence of such events has been found onshore such as marine sand sheets deposited inland, barrier breaches or supralittoral boulder deposits in elevated positions significantly exceeding the size of the largest boulders moved by recent severe hurricanes (Khan et al., 2010; Scheffers and Scheffers, 2006), e.g. on Aruba, Bonaire and Curaçao (ABC Islands), the Antillean Arc, Anegada, Barbados, Jamaica, the Grand Caymans and the Bahamas (Jones and Hunter, 1992; Scheffers, 2004, 2005; Kelletat et al., 2005; Robinson et al., 2006; Atwater et al., 2010). The high tsunami risk is also confirmed by O'Loughlin and Lander (2003) who compile 53 reliable tsunami occurrences in the Caribbean region within the last 500 years of written history.

On the island of Bonaire in the southern Caribbean (Fig. 1), the lack of historical accounts of tsunamis (O'Loughlin and Lander, 2003) stands in a remarkable contrast to the massive circumlittoral boulder deposits some of which have been associated with tsunamigenic dislocation (Scheffers, 2004, 2005). However, the interpretation of these boulders as storm or tsunami deposits has been ques- 


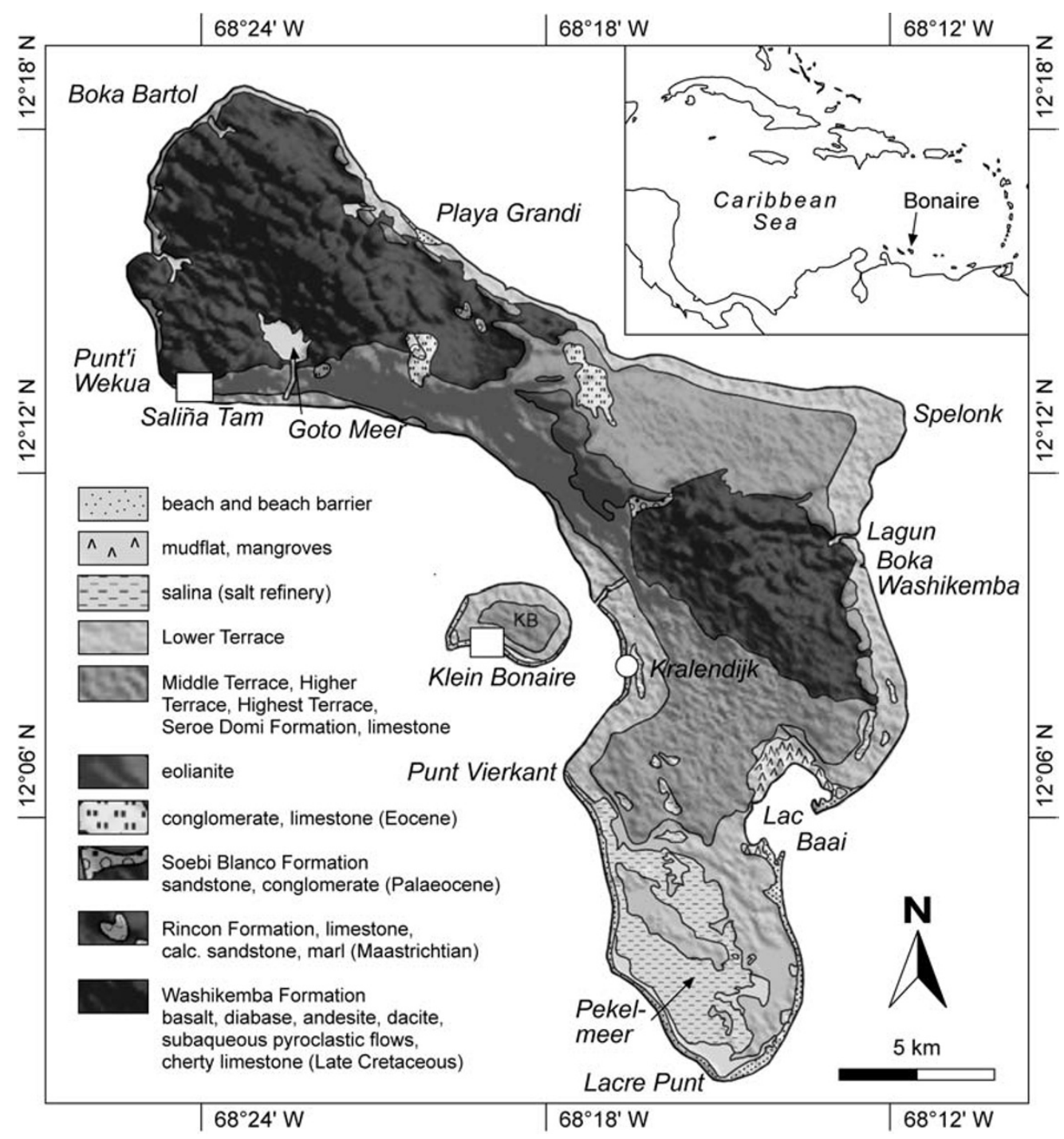

Fig. 1. Geological overview of Bonaire based on previous mapping by Pijpers (1933), Westermann and Zonneveld (1956) and De Buisonjé (1974) as well as SRTM elevation data (http://dds.cr.usgs.gov/srtm) showing sites from this study (white rectangles) and Engel et al. (2010).

tioned (cf. Morton et al., 2008; Spiske et al., 2008). For this reason, we have chosen to use coastal stratigraphical contexts (lagoons, alluvial flats) of Bonaire's coastline in order to examine the extreme wave history of the southern Caribbean and to evaluate the impact of those waves on shoreline dynamics.

The main goals of this paper are to reconstruct midto late Holocene coastal environments and to identify and date extreme wave deposits, as well as to differentiate between sedimentary signatures of tsunamis and tropical cyclones (in the Caribbean region referred to as hurricanes) of west (leeward) Bonaire. The signatures are compared with those of fine-grained extreme-wave deposits from the eastern (windward) coast (cf. Engel et al., 2009, 2010) and with implications of the supralittoral coarse-clast record (Scheffers, 2005; Morton et al., 2008; Watt et al., 2010). Research on palaeotsunami deposits in coastal areas where tsunami occurrence has never been documented may provide a scientific basis for:

- the designation of high-risk areas,

- the creation of public awareness for a generally under- estimated coastal hazard, and

- local disaster mitigation planning (cf. Rhodes et al., 2006).

\section{Study Sites}

The island of Bonaire (Fig. 1) comprises a volcanic core (Late Cretaceous, Washikemba Formation) and a series of surrounding palaeo-reef terraces (Neogene-Quaternary) forming steep cliffs along the coast as well as minor relics of Palaeogene deposition. Slow tectonic uplift (around $5 \mathrm{~cm} / \mathrm{ka}$ ), tilting and Quaternary sea-level fluctuations fostered the development of a sequence of reefal limestone terraces. The lowermost palaeo-reef stages, the Middle Terrace (MT) and the Lower Terrace (LT), relate to MIS 7 or earlier and 5e, respectively (Herweijer and Focke, 1978).

Bonaire has an arid climate and experiences persistent tradewinds from the east, with easterly storms and occasional hurricanes during the period between June and November. The coasts have a microtidal regime $(\mathrm{c} .0 .3 \mathrm{~m})$. While the eastern shore is exposed constantly to high wave energy, the western, leeward shore-including the study 


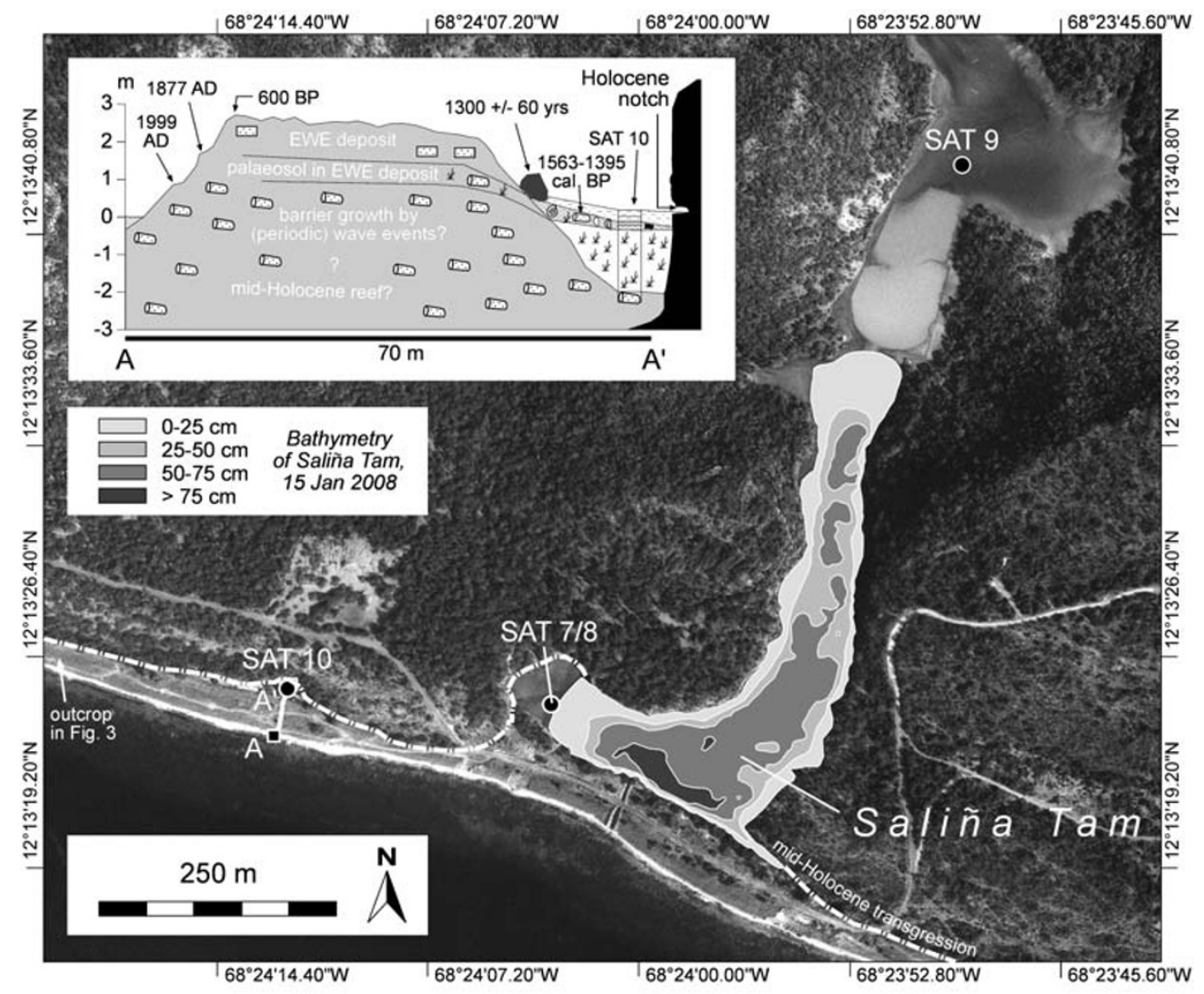

Fig. 2. Aerial view of Saliña Tam (1996), western Bonaire (Fig. 1), providing information on coring sites and bathymetry of the water body. The cross section $\mathrm{A}-\mathrm{A}^{\prime}$ was measured by DGPS. The internal structure of the barrier is also shown on Fig. 3. The ESR age of a large head coral (1300 \pm 60 a) is taken from Scheffers (2005). The back-barrier stratigraphy is based on SAT 10 (Fig. 9). Dates on the seaward berm indicate morphological traces of hurricanes Lenny (1999), Tekla (1877) and an unspecified EWE c. 600 years ago (Scheffers, 2005). A key to symbols is on Fig. 5. EWE = extreme wave event.

sites of Saliña Tam and Klein Bonaire-is calmer and thus characterised by a vertically narrow notch and a flourishing fringing reef (Focke, 1978). Nevertheless, increased wave action triggered by tropical cyclones in the last decade, e.g. Hurricane Lenny in 1999, taking an unusual west-to-east track, had significant morphological effects on the coral rubble beaches (Scheffers, 2005) and destroyed large parts of the living reef (Bries et al., 2004). The southern part of the western (leeward) coastline from Lacre Punt to Punt Vierkant is covered by coral debris and boulders of up to $2 \mathrm{t}$, most of which were washed onshore in 1999. Several boulders of up to $20 \mathrm{t}$ lie on top of the lower marine terrace LT between Kralendijk and Goto Meer (Scheffers, 2005).

In search of subsurface extreme wave deposits along the leeward side of Bonaire, the former inland bay of Saliña Tam and the shallow back-barrier lagoon of southern Klein Bonaire (Fig. 1) were chosen for stratigraphic investigations. The sites are characterised by background sedimentation from shallow standing water (brackish to hypersaline) and occasional fluvial input (Saliña Tam) behind a barrier of coral rubble. At some places thick beds of mangove peat are present. Event layers consist of shallow marine sands, shells, and coral fragments.

\subsection{Saliña Tam}

Saliña Tam is a ria-like landform (Scheffers, 2004, 2005) locally referred to as boka (Fig. 2). It is the lower section of a valley, draining a part of the undulating topography of northwestern Bonaire (Washikemba Formation, Fig. 1) and intersecting the LT and MT. The main morphodynamic processes are linear erosion during the latest Pleistocene base-level fall. At the entrance of Bonaire's bokas, LT incision amounts up to $16 \mathrm{~m}$ below present sea level (De Buisonjé, 1974).

Postglacial sea-level rise flooded Saliña Tam. The boka is separated from the open sea by a bar of sand, coral rubble and beachrock reaching a width of up to $70 \mathrm{~m}$ and a height of up to $3 \mathrm{~m}$ above present sea level (a.s.l) (Figs. 2 and 3 ). When this bar formed and whether it formed due to long-term morphodynamic processes (e.g. longshore drift) (Zonneveld et al., 1977) or due to extreme wave events (Scheffers, 2005; Morton et al., 2008) is a subject of this paper. Today, salinity of the bokas is high (up to $120 \%$ o below the halocline of Goto Meer during summer (Kobluk and Crawford, 1990)) and the water table is low due to low permeability of the seaward barrier, low precipitation most time of the year, as well as to high evaporation (De Buisonjé, 1974).

Approximately $250 \mathrm{~m}$ west of Saliña Tam, the coastal barrier of coral rubble is separated from the inactive cliff of the LT by a morphological depression filled with sediment (site SAT 10). At ground level the uppermost part of a bioerosive notch is visible. Numerous coral boulders ( $a$ axes up to $2 \mathrm{~m}$ ) are clustered at the landward avalanching face of the barrier (Fig. 2) (Scheffers, 2005; Morton et al., 


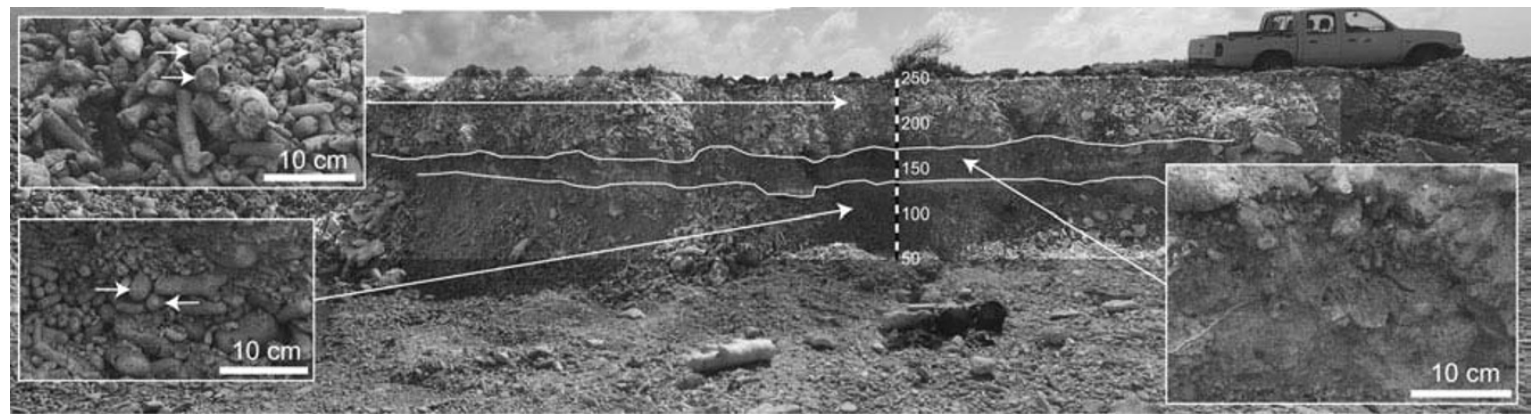

Fig. 3. Outcrop of the ridge of coral rubble near Saliña Tam (Fig. 2). Its stratigraphy is divided into three parts. On top there is a unit of well sorted angular fragments of Acropora cervicornis (c. $80 \mathrm{~cm}$, upper left close-up photo). It is separated from the basal unit of well-sorted and well-rounded coral rubble (lower left close-up photo) by a palaeosol developed in a layer of poorly sorted carbonate sand and coral material (close-up photo on the right). The elevation is shown in $\mathrm{cm}$ above mean sea level.

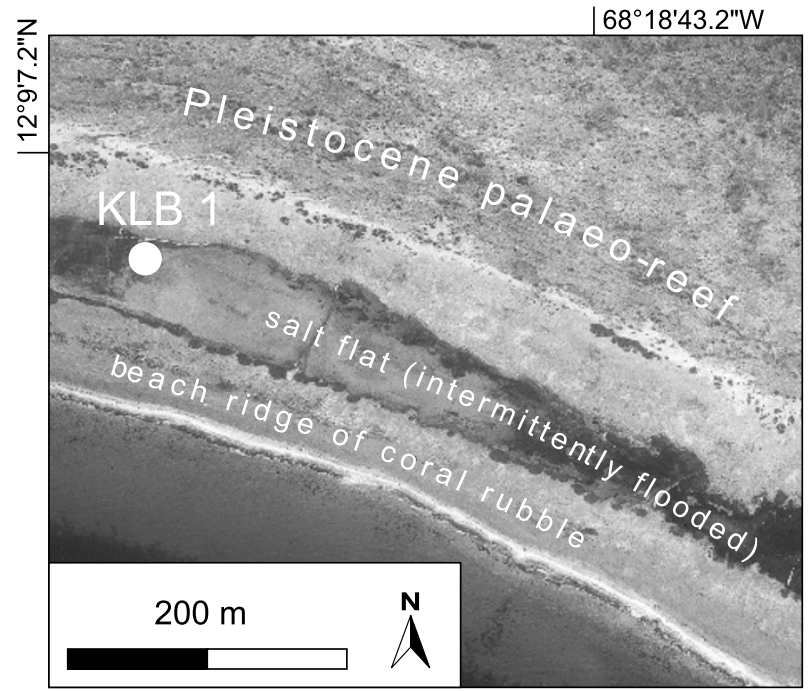

Fig. 4. Aerial view of coring site KLB 1 on southern Klein Bonaire (Fig. 1) at the back of a broad, active ridge of coral rubble.

\section{8).}

\subsection{Southern Klein Bonaire}

Klein Bonaire is a small and flat island off the leeward coast of Bonaire entirely consisting of MT and LT limestone. It is surrounded by ridges of sand and coral rubble (De Buisonjé, 1974). The MT and LT deposits lie significantly lower compared to their counterparts on the main island, possibly due to tilting. In the southern part, the surface of the LT gently slopes towards the barrier forming an area of shallow water and back-barrier sedimentation (Fig. 4).

\section{Methods}

In order to reconstruct sedimentation processes and palaeoenvironments at the two sites, we examined five sediment cores for their sedimentological, geochemical and faunal composition. Cores allow for sampling relatively great depths regardless of the groundwater table, though they only provide one-dimensional insights into the stratigraphy and may hamper the identification of certain sedimentological features indicative of tsunami or storm deposition. Four vibracores $(d=6.0$ and $5.0 \mathrm{~cm})$ were taken at Saliña Tam with an engine-driven Atlas Copco 248 coring device. The maximum coring depth was $11 \mathrm{~m}$ b.s. (below surface). Two of them were taken with open steel probes (SAT 7 and 10), and in these cases the cores were cleaned, photographed, documented and sampled in the field for multi-proxy analyses. Two vibracores were preserved in closed PVC tubes, which were split in the laboratory (SAT 8 and 9). The fifth core was a $1.28-\mathrm{m}$ PVC push core $(d=7.5 \mathrm{~cm})$ also split in the laboratory (KLB 1).

\subsection{Non-destructive core analysis}

The inorganic element composition of KLB 1 and SAT 8 was determined using an ITRAX X-ray fluorescence (XRF) core scanner (Cox Analytical Systems). The device was prepared with a $3 \mathrm{~kW}$ Mo X-ray tube set to $30 \mathrm{kV}$ and $30 \mathrm{~mA}$. It enabled analyses of semi-quantitative variations of elements from $\mathrm{Al}$ to $\mathrm{U}$ by scanning $1 \mathrm{~mm}$ steps for $20 \mathrm{~s}$ each. Element amounts are shown as count rates (cr) representing estimates of the relative concentrations in the sediment (Croudace et al., 2006).

\subsection{Analyses using core samples}

For a sufficient amount of sediment material each sample from the open cores (SAT 7 and 10) represents sections of 5-10 cm from significant stratigraphic units. The closed cores (SAT 8 and 9, KLB 1) were sampled selectively in 1-2 cm sections. Samples were air-dried and broken up by hand with a mortar and pestle. The carbonate content of the fine-grained fraction $(<2 \mathrm{~mm})$ of all vibracores was gasvolumetrically measured following the Scheibler method. Loss on ignition (LOI) was determined by oven-drying at $105^{\circ} \mathrm{C}$ for $12 \mathrm{~h}$ and ignition in a muffle furnace at $550^{\circ} \mathrm{C}$ for $4 \mathrm{~h}$ (Beck et al., 1993). The wet sieve-pipette technique (Köhn, 1928) was applied for analysing the grain size distribution after pre-treatment of the aliquots with $\mathrm{Na}_{4} \mathrm{P}_{2} \mathrm{O}_{7}$ $(55.7 \mathrm{~g} / \mathrm{l})$ for aggregate dispersion. Shell material was not removed. Results were processed with GRADISTAT software (Blott and Pye, 2001). Mean grain size was calculated after Folk and Ward (1957) and grain sizes were classified after Arbeitsgemeinschaft Boden (2005).

Selected samples were treated with $\mathrm{H}_{2} \mathrm{O}_{2}(3 \%)$ and fractionated by sieving (mesh sizes of $0.063 \mathrm{~mm}, 0.2 \mathrm{~mm}$ and $1.0 \mathrm{~mm}$ ) for quantitative microfossil investigations. Microfaunal remains were picked from residue splits containing at least 300 specimens, if present within the sample, and were taxonomically identified using a low-power binocular microscope. High magnification light microscopy and scan- 


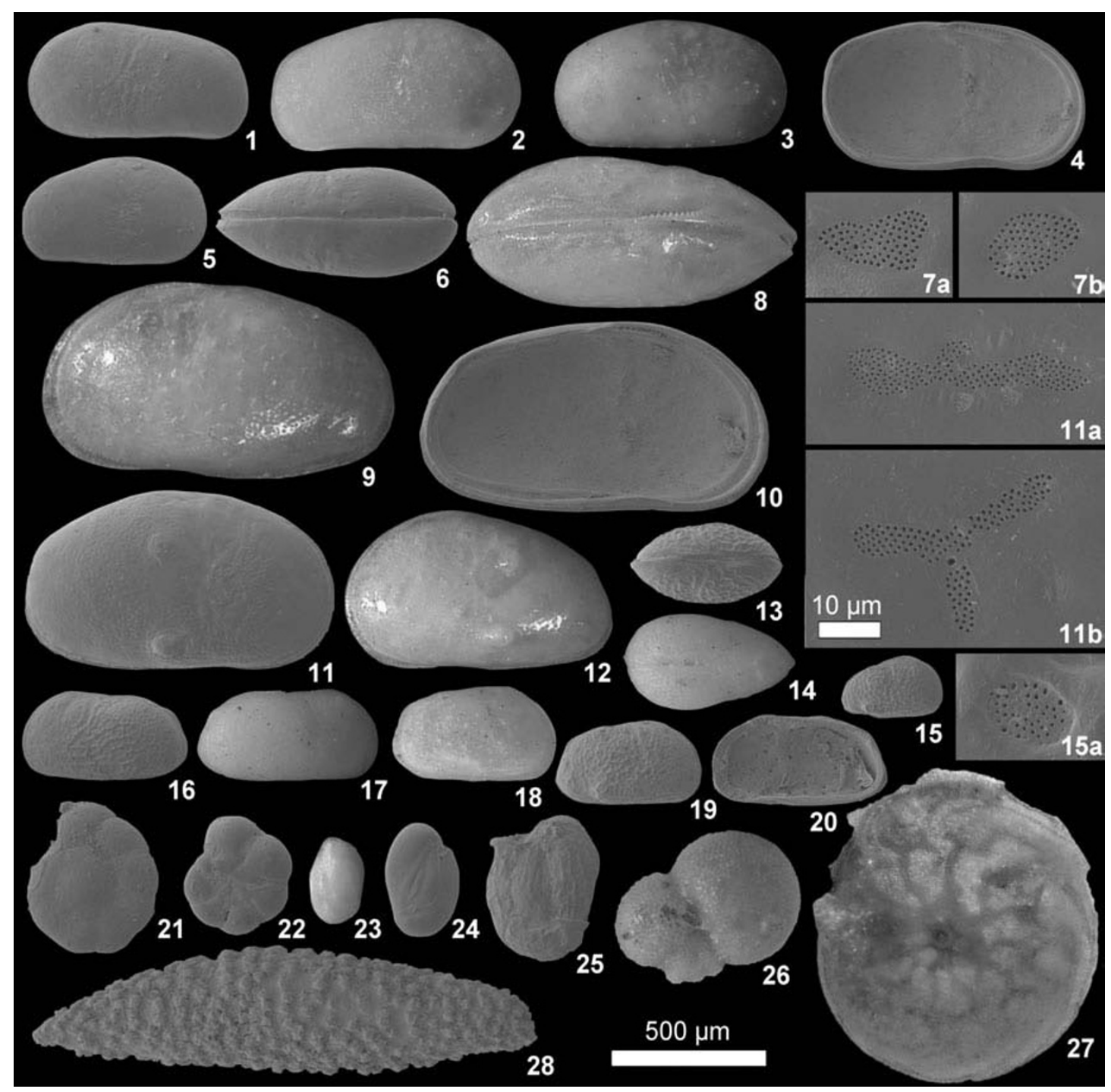

Fig. 5. Characteristic microfossils from Saliña Tam and Klein Bonaire: 1)-20) Ostracoda, 21)-27) Foraminifera, 28) Octocorallia. 1)-7) Cyprideis sp.: 1) left side of a male carapace, SAT $9(2.61-2.50 \mathrm{~m}$ b.s.); 2$)$ right side of a male carapace, SAT $8(2.51-2.43 \mathrm{~m}$ b.s.); 3$)$ right side of a female carapace, SAT 8 (1.75-1.65 m b.s.); 4) interior of a female left valve, SAT 9 (2.61-2.50 m b.s.); 5) juvenile right valve, SAT 9 (2.61-2.50 m b.s.); 6) dorsal view of a female carapace, SAT $9(2.61-2.50 \mathrm{~m}$ b.s.); 7) sieve pores of a female left valve, SAT $9(2.61-2.50 \mathrm{~m}$ b.s.). 8)-12) Cyprideis beaveni (Tressler and Smith, 1948): 8) dorsal view of a female carapace, SAT 8 (2.43-2.38 m b.s.); 9) male left valve, SAT 8-13; 10) interior view of a male left valve, SAT 9 (2.61-2.50 m b.s.); 11) noded female right valve and two sieve pores, SAT 9 (2.61-2.50 m b.s.); 12) noded juvenile left valve, SAT 8 (2.57-2.51 m b.s.). 13)-20) Perissocythere cribrosa (Klie, 1933): 13) dorsal view of a female carapace, SAT 8 (3.00-2.90 m b.s.); 14) dorsal view of a male carapace, SAT 8 (3.05-2.95 m b.s.); 15) right side of a juvenile valve and a sieve pore, SAT 8 (2.86-2.81 m b.s.); 16) left side of a male carapace, SAT 8 (3.25-3.20 m b.s.); 17) right side of a male carapace, SAT 8 (3.05-2.95 m b.s.); 18) right side of a female carapace, SAT 8 (2.09-2.00 m b.s.); 19) female right valve, SAT 8 (3.25-3.20 m b.s.); 20) internal view of a male right valve, SAT 8 (3.00-2.90 m b.s.). 21)-22) Ammonia tepida? (Cushman, 1926): 21) spiral view, last chamber missing, KLB 1 (0.69-0.68 m b.s.); 22) umbilical view, KLB 1 (0.69-0.68 m b.s.). 23-25) Miliolinids, lateral views: 23) Quinqueloculina seminula (Linnaeus, 1758), SAT 8 (2.29-2.25 m b.s.); 24) Miliolinella sp. I, SAT 8 (2.80-2.73 m b.s.); 25) Miliolinella sp. II, KLB 1 (0.58-0.57 m b.s.). 26) Globigerinoides cf. immaturus (Leroy, 1939), SAT 8 (2.59-2.40 m b.s.). 27) Amphistegina sp., SAT 8 (2.59-2.40 m b.s.). 28) Sclerite of an alcyonarian coral, SAT 8 (3.25-3.20 m b.s.). Photos 2, 3, 8, 9, 12, 14, 17, 18, 23, 26, and 27 are light microscope photos, all others are scanning electron microscope (SEM) pictures.

ning electron microscopy (SEM) supported photographic documentation and taxonomic identification (Fig. 5). Ostracods and foraminifers were identified to the species level if possible; all other fossils were identified to group level. The state of preservation of fossil groups was documented for distinguishing reworked and (par-)autochthonous specimens.

In order to identify sediment provenance areas (marine, terrestrial-autochthonous, terrestrial-allochthonous), the mineralogical spectrum of selected powder samples was investigated by means of a Siemens 5000D X-ray diffrac- tometer. XRD investigations were carried out using $\mathrm{Cu} \mathrm{K} \alpha$ radiation $(40 \mathrm{kV}, 40 \mathrm{~mA})$. Samples were run from $10^{\circ}$ to $70^{\circ} 2 \Theta$. For semiquantitative interpretation X'Pert HighScore Plus software (PANalytical) was used, which is based on the Rietveld refinement technique fitting a calculated XRD profile to the measured pattern and assigning abundances of minerals.

The chronostratigraphy of all sites is based on ${ }^{14} \mathrm{C}$-AMS analyses (Table 1). Radiocarbon dates of marine shells were corrected for a regional marine reservoir effect of $\Delta R=$ -49 (Radtke et al., 2003). ${ }^{14} \mathrm{C}$-AMS data were converted to 
Table 1. ${ }^{14} \mathrm{C}$-AMS dates for samples from Saliña Tam and Klein Bonaire were carried out at the radiocarbon laboratoriy of the University of Georgia at Athens (USA).

\begin{tabular}{lcclccc}
\hline \multicolumn{1}{c}{ Sample } & Depth $(\mathrm{cm}$ b.s. $)$ & Lab ID UGAMS\# & Material & $\delta^{13} \mathrm{C}(\%)$ & ${ }^{14} \mathrm{C}$ age & Age cal BP $(2 \sigma)$ \\
\hline SAT 7/11 & $273^{*}$ & 3212 & gastropod & -3.74 & $2740 \pm 25$ & $2607-2462$ \\
SAT 8/7 & 243 & 5996 & gastropod & 0.3 & $2280 \pm 20$ & $2021-1869$ \\
SAT 8/28 & 272 & 7577 & gastropod & -2.8 & $3110 \pm 20$ & $3039-2857$ \\
SAT 9/1 & 355 & 5999 & peat & -24.4 & $4030 \pm 25$ & $4568-4424$ \\
SAT 9/2 & 360 & 6000 & peat & -26.4 & $4160 \pm 25$ & $4826-4584$ \\
SAT 9/a & 325 & 7578 & gastropod & -3.8 & $3360 \pm 25$ & $3359-3206$ \\
SAT 10/4 Ko & 50 & 7579 & coral & -3.0 & $1890 \pm 25$ & $1563-1395$ \\
SAT 10/10 & 210 & 7580 & peat & -26.9 & $2080 \pm 25$ & $2295-2004$ \\
KLB 1/a 43 & 43 & 7588 & gastropod & -4.1 & $3240 \pm 25$ & $3236-3028$ \\
KLB 1/c 70 & 70 & 7589 & gastropod & -5.3 & $3570 \pm 30$ \\
\hline
\end{tabular}

*Depth information is as recorded in core SAT 7. However, the sediment layer lies approx. $15 \mathrm{~cm}$ deeper compared to parallel core SAT 8 , most likely due to compaction differences between open and closed coring techniques.

sidereal years by means of CALIB 6.0.1 software (Reimer et al., 2009). For age interpretation the $2 \sigma$ error ( $p=$ 0.956) was taken into account.

\section{Sedimentary Record of Saliña Tam \\ 4.1 The back-barrier record-SAT 7/8}

Sediment cores SAT 7 and SAT 8 represent the stratigraphy directly behind the broad ridge of coral rubble separating Saliña Tam from the open sea (Fig. 2). One open (SAT 7) and one closed (SAT 8) core were taken at the same site. The environmental interpretation of the cores is given on Figs. 6 and 7.

The lower $7.75 \mathrm{~m}$ (11.00-3.25 m b.s.) at site SAT 7/8 consist of a coquina of fine shell debris (light grey bivalves, mainly Ctena orbiculata, and gastropods, mainly Bulla striata, Caecum sp.), carbonate sand (on Bonaire predominantly fragments of Halimeda sp.) and bryozoan fragments showing a high degree of abrasion. $\mathrm{Ca}$ and $\mathrm{Sr}$ concentrations are high and slightly decrease in the uppermost part. At 3.35-3.25 m b.s., the coquina contains lagoonal ostracods (Cyprideis beaveni [partly noded], Cyprideis sp., Perissocytheridea cribrosa; Fig. 5), small benthic foraminifers (miliolinids), and remains of small fish and echinoderms.

The overlying deposit of very dark brown sandy silt (3.25-2.82 m b.s.) shows an abrupt decrease in $\mathrm{CaCO}_{3}$ and increasing LOI values. From $3.00-2.82 \mathrm{~m}$ b.s. the unit is stratified and contains thin layers of calcite, aragonite and gypsum. Concentrations of $\mathrm{K}, \mathrm{Ti}$ and $\mathrm{Br}$ increase. Cyprideis beaveni (partly noded), Cyprideis sp., Perissocytheridea cribrosa and miliolinid foraminifers are still present. Mollusc shells, bryozoan and echinoderm remains are absent.

Between 2.82-2.60 $\mathrm{m}$ b.s. there are ten graded sequences with a thickness of 1-6 cm (Fig. 7). The lower boundary of each bed is erosional. The bottom parts of the sequences contain partly fragmented shells of Cerithium sp. and coarse carbonate sand. The upper parts are silty mud containing rafted plant material. Most of the graded sequences start with a sudden increase in $\mathrm{Ca}$, which gradually decreases upwards (Fig. 7). Peaks of Br correlate with the upper parts of the graded beds and identify high concentration of organic matter (Chagué-Goff et al., 2002; Pérez et al., 2010). Sim- ilar to the underlying unit, bulk samples of the entire unit contain high amounts of brackish foraminifers and ostracods, but also scattered fragments of corals, mollusc shells, bryozoans and echinoderms. It is noteworthy that only the lowermost sequence contains planktonic foraminifers and high abundances of reworked ostracods (thick carbonate encrustations). A shell of Cerithium sp. (2.72 m b.s., bed EWE V) was radiocarbon dated to 3039-2857 cal BP.

The overlying unit (2.60-2.38 m b.s.) is pale white and almost entirely consists of $\mathrm{CaCO}_{3}$. Four sequences - three normally graded beds containing shells of Cerithium sp. and coarse sand at the bottom, and one inversely graded bed (Fig. 7)-were identified. A very thin mud drape covers the second graded sequence. The section contains reworked valves of brackish ostracods as well as miliolinid foraminifers, Amphistegina, Discorbis, Alcyonaria and fragments of Malacostraca, Scleractinia and several other marine forms. Planktonic foraminifers (Globigerinoides cf. immaturus) were also located (Fig. 5). Aragonite is the dominating mineral. The amount of quartz is very low. From the lower part of this unit (in SAT 7) as well as from $2.43 \mathrm{~m}$ b.s. (in SAT 8) cerith shells were radiocarbon dated to 2607-2462 and 2021-1869 cal BP (Table 1, Figs. 6 and 7).

Between 2.38 and $2.30 \mathrm{~m}$ b.s. are three fining-up sequences, with distinct lower contacts consisting of a very thin basal layer of carbonate sand and a thicker muddy, organic-rich part. The spectrum of microfossils covers Cyprideis sp. and P. cribrosa, and some tests of miliolinid foraminifers and Amphistegina. The amount of marine biogenic particles is significantly reduced compared to the underlying graded beds.

The overlying units represent the background sedimentation: $\mathrm{Ca}$ and $\mathrm{Sr}$ are lower than previously, and LOI, Ti, Br and $\mathrm{K}$ values higher. The most abundant mineral is quartz. Several plant remains (leaf fragments, wood) and angular stones were found. A thin unit of alternating silt layers of carbonate and gypsum occurs between 2.30 and $2.26 \mathrm{~m}$ b.s. From $1.00-0.76 \mathrm{~m}$ b.s., $\mathrm{CaCO}_{3}$ values and mean grain size are higher than background and the sediment is more poorly sorted. 


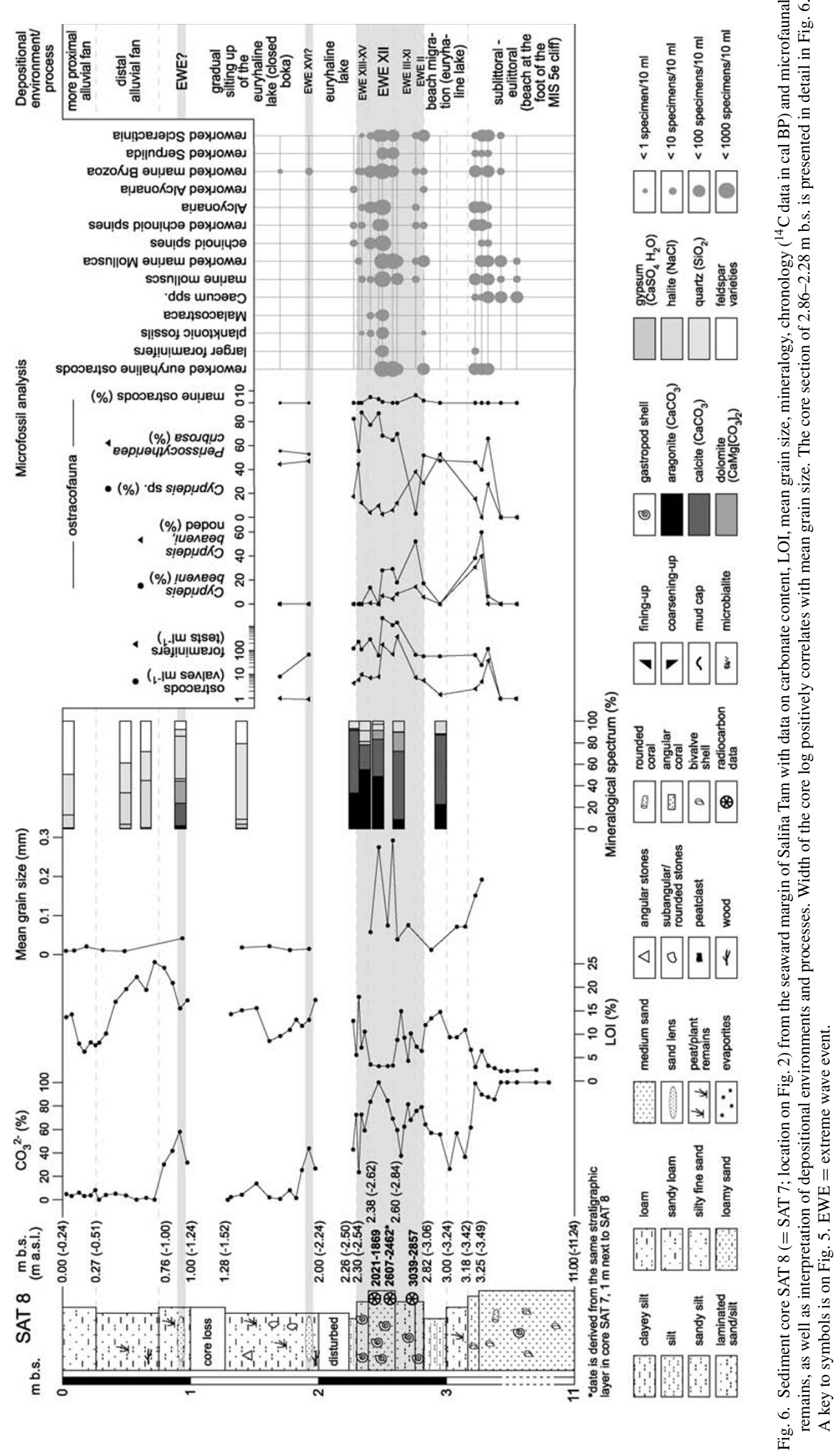




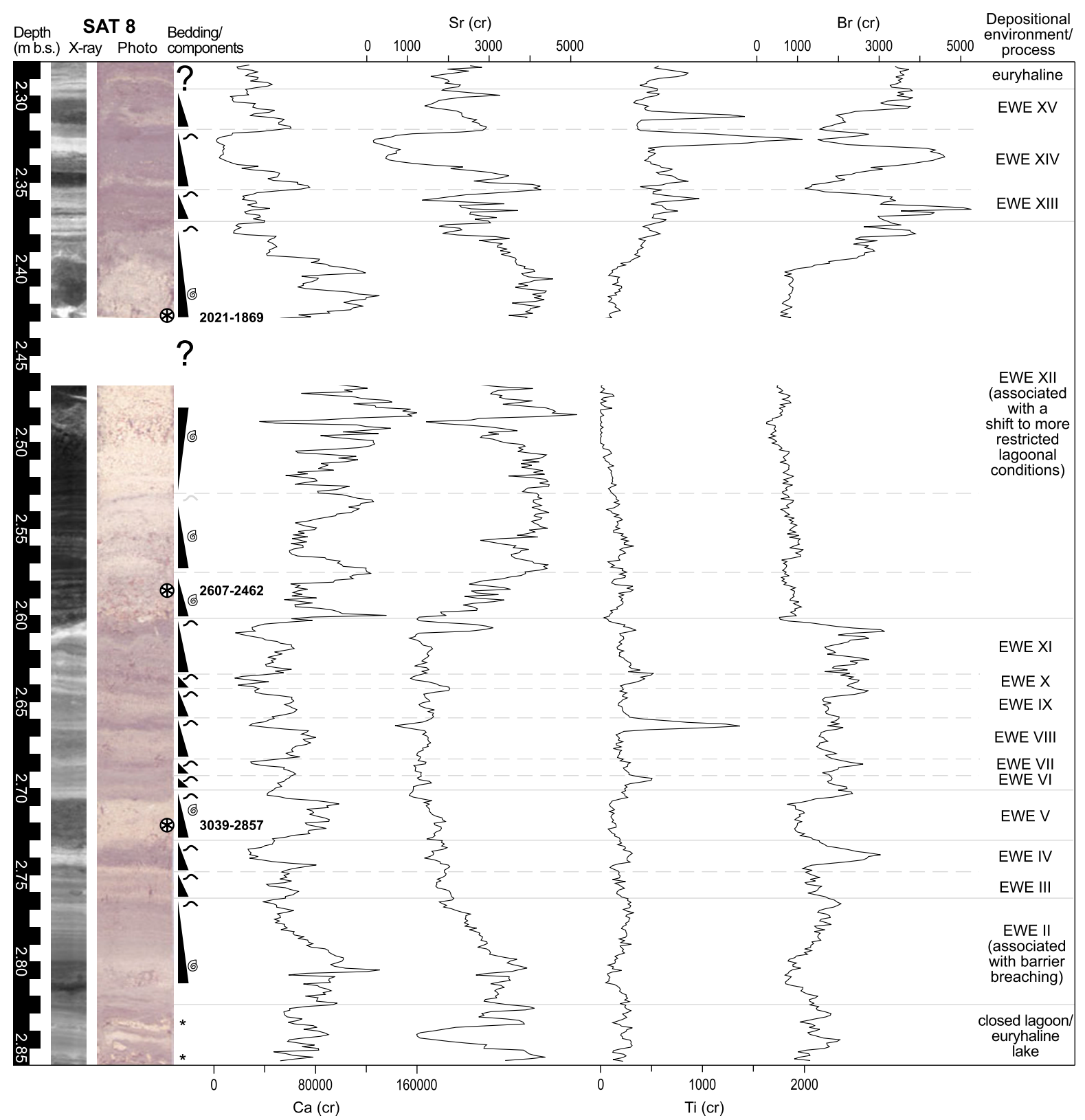

Fig. 7. X-ray, photograph, and high-resolution XRF data (Ca, $\mathrm{Sr}, \mathrm{Ti}, \mathrm{Br}$; cr $=$ XRF count rates) of core section $2.86-2.28 \mathrm{~m}$ b.s. from SAT 8 (Figs. 2 and 5), labeled with basic interpretation of depositional environments and processes. ${ }^{14} \mathrm{C}$ ages are displayed as cal BP. A key to symbols is on Fig. 5 . $\mathrm{EWE}=$ extreme wave event.

\subsection{The landward alluvial plain-SAT 9}

SAT 9 is located c. $800 \mathrm{~m}$ from the shoreline, at the alluvial plain north of the boka (Fig. 2). The terrain is seasonally flooded by the intermittent river. Proxy data and core interpretation are shown in Fig. 8.

From the base, $5.00 \mathrm{~m}$, to $3.49 \mathrm{~m}$ b.s. there is a unit of black peat with high LOI and low $\mathrm{CaCO}_{3}$ concentrations as well as a large number of juvenile smooth bivalves and several specimens of miliolinid foraminifers and Ammonia spp. (Fig. 5). Plant fragments from 3.60 and $3.55 \mathrm{~m}$ b.s. were dated by ${ }^{14} \mathrm{C}$ to $4826-4584$ and $4568-4424$ cal BP.

The peat is overlain by half a meter of light olive brown carbonate mud with an erosive basal contact (3.49-2.94 m b.s.) and numerous gypsum crystals. Carbonate content reaches up to $60 \%$. Angular stones and complete cerith shells are present in the matrix. C. beaveni (partly noded) and P. cribrosa as well as several miliolinid foraminifers compose the microfauna. Juvenile smooth bivalves are rare. No shell material indicating open marine or reefal origin was identified.

From 2.94 to $2.77 \mathrm{~m}$ b.s. the sediment consists of thin alternating beds of carbonate sand (light brown) and grey layers of silty clay, both containing gypsum and halite crystals. While sand layers are linked to small peaks in $\mathrm{CaCO}_{3}$, silty clay layers coincide with peaks in LOI. C. beaveni (partly noded), Cyprideis sp. as well as miliolinid foraminifers are abundant, whereas $P$. cribrosa is rare. Several ostracods show signs of reworking.

The overlying metre (2.77-1.74 m b.s.) consists of olive grey sandy silt showing an upward decrease in $\mathrm{CaCO}_{3}$. At 1.74-1.65 m b.s. there are three layers of coarse gypsum crystals. Above, the uppermost unit of SAT 9 consists of 


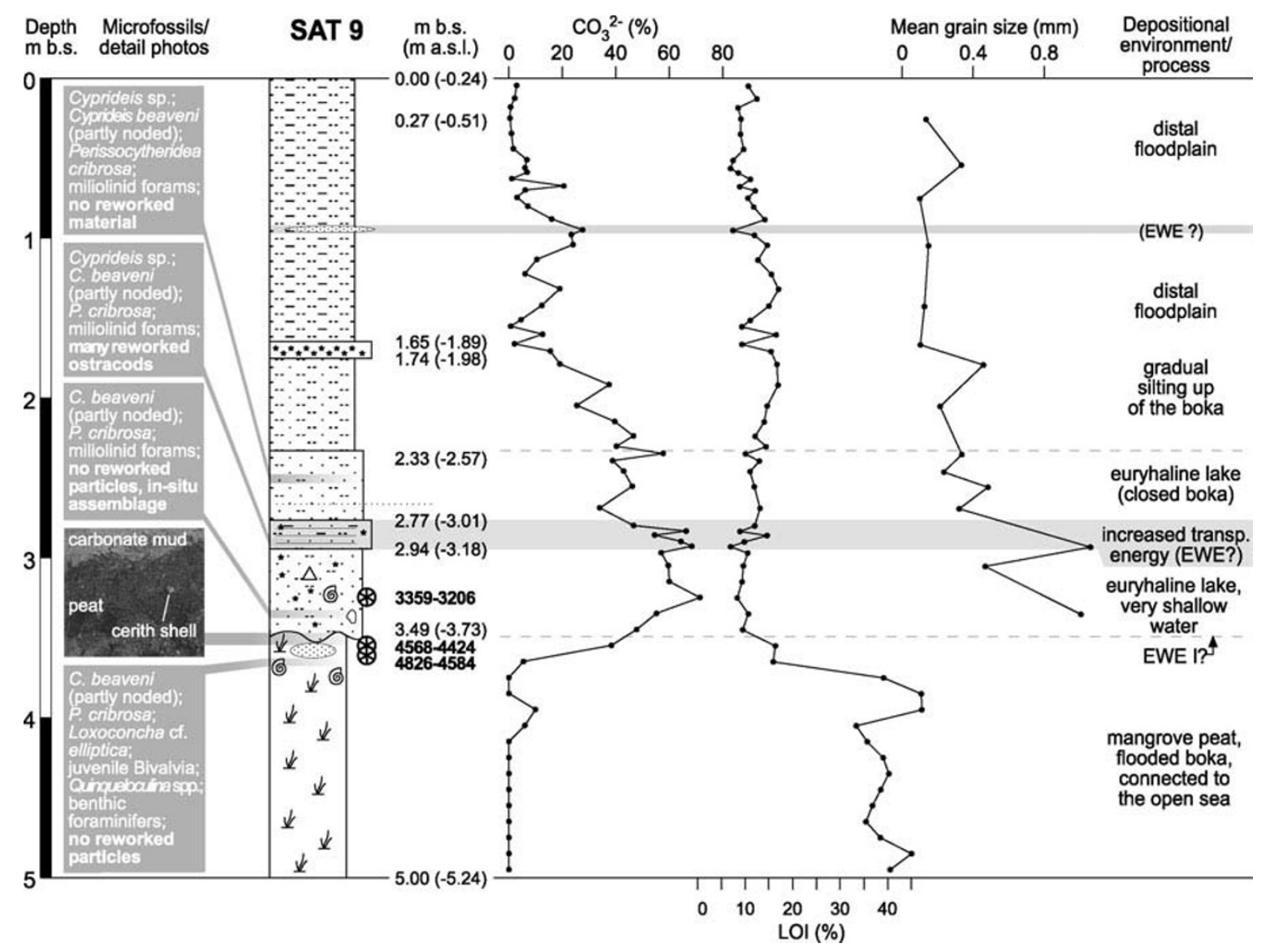

Fig. 8. Sediment core SAT 9 (located on Fig. 2) from the landward margin of Saliña Tam with data on carbonate content, LOI, mean grain size, microfaunal remains and chronology $\left({ }^{14} \mathrm{C}\right.$ data in cal BP), as well as interpretation of depositional environments and processes. Width of the core log positively correlates with mean grain size. A key is provided in Fig. 5. EWE = extreme wave event.

very dark grey clayey silt with several reddish dark brown sections. The ostracod fauna is brackish, noded C. beaveni decrease. A minor peak in $\mathrm{CaCO}_{3}$ occurs at $0.90-$ $1.00 \mathrm{~m}$ b.s.

\subsection{Between Saliña Tam and Punt'i Wekua-SAT 10}

SAT 10 (Fig. 9) is located on a narrow alluvial plain between the ridge of coral rubble and the LT cliff (Fig. 2). At ground level, this cliff is cut horizontally by a sea levelrelated bioerosive notch (c. $0.00-0.20 \mathrm{~m}$ a.s.1.). The core reached only $2.45 \mathrm{~m}$ due to a thick layer of coral rubble (mainly Acropora cervicornis).

The coral rubble is overlain by a unit of very dark brown mangrove peat (2.17-0.52 m b.s.) dated to 2295-2004 cal $\mathrm{BP}$ at $2.10 \mathrm{~m}$ b.s. An erosional boundary separates the peat from a carbonate sand layer $(0.52-0.40 \mathrm{~m}$ b.s., layer A in Fig. 9) containing reworked peat remains, shell debris and two $4 \mathrm{~cm}$-fragments of Diploria sp. (1563-1395 cal BP). In a trench at the site (photo inset in Fig. 9), even coarser coral shingle and beachrock slabs containing branches of $A$. cervicornis were present in this layer. At $0.40-0.30 \mathrm{~m}$ b.s. (layer B in Fig. 9) the sediment consists of poorly sorted, grey silty sand with shell debris. The overlying strata consist of dark greyish brown $(0.30-0.17 \mathrm{~m} \mathrm{b.s.)}$ to dark yellowish brown $(0.17-0.00 \mathrm{~m}$ b.s.) silty matrix with reduced carbonate sand components (layers C and D in Fig. 9).

\subsection{The sedimentary record of southern Klein- Bonaire-KLB 1}

Core KLB 1 (Fig. 10) was recovered behind the coastal barrier of southern Klein Bonaire (Fig. 4), less than $100 \mathrm{~m}$ from the swash zone. The site is a shallow pond characterized by algae mats, mud sedimentation, and carbonate precipitation.

The basal part (1.28-1.20 m b.s.) consists of light olive grey sandy silt containing several gastropod shells, a lens of root material, and a brackish-marine foraminifer assemblage dominated by miliolinid foraminifers and Ammonia spp. (both taxa highly abundant), marine mollusc shells, and only few ostracods. Between 1.20 and $0.70 \mathrm{~m}$ b.s. is a layer of pure mangrove peat void of $\mathrm{Ca}$ and $\mathrm{Sr}$ and exhibiting a high plateau in the $\mathrm{Br}$ curve. The peat is unconformably overlain by two thin graded beds $(0.70-0.67 \mathrm{~cm}$ b.s.; $0.67-$ $0.66 \mathrm{~cm}$ b.s.), both characterized by basal carbonate sand with well-preserved gastropod shells and shell fragments, an upward decrease in $\mathrm{Ca}, \mathrm{a} \mathrm{Br}$ peak in the upper part corresponding to a mud cap (Chagué-Goff et al., 2002; Pérez et al., 2010) and a large number of reworked brackish ostracods. The amount of aragonite is more than $60 \%$. Radiocarbon dating of a cerith shell $(0.70 \mathrm{~m}$ b.s.) yielded an age of 3614-3426 cal BP. The thin sand beds are overlain by a well sorted layer of light yellowish brown sandy silt (0.66$0.64 \mathrm{~m}$ b.s.) rich in $\mathrm{Ca}$ and $\mathrm{Sr}$. Aragonite is significantly reduced in favour of calcite. A thin layer of mangrove peat 

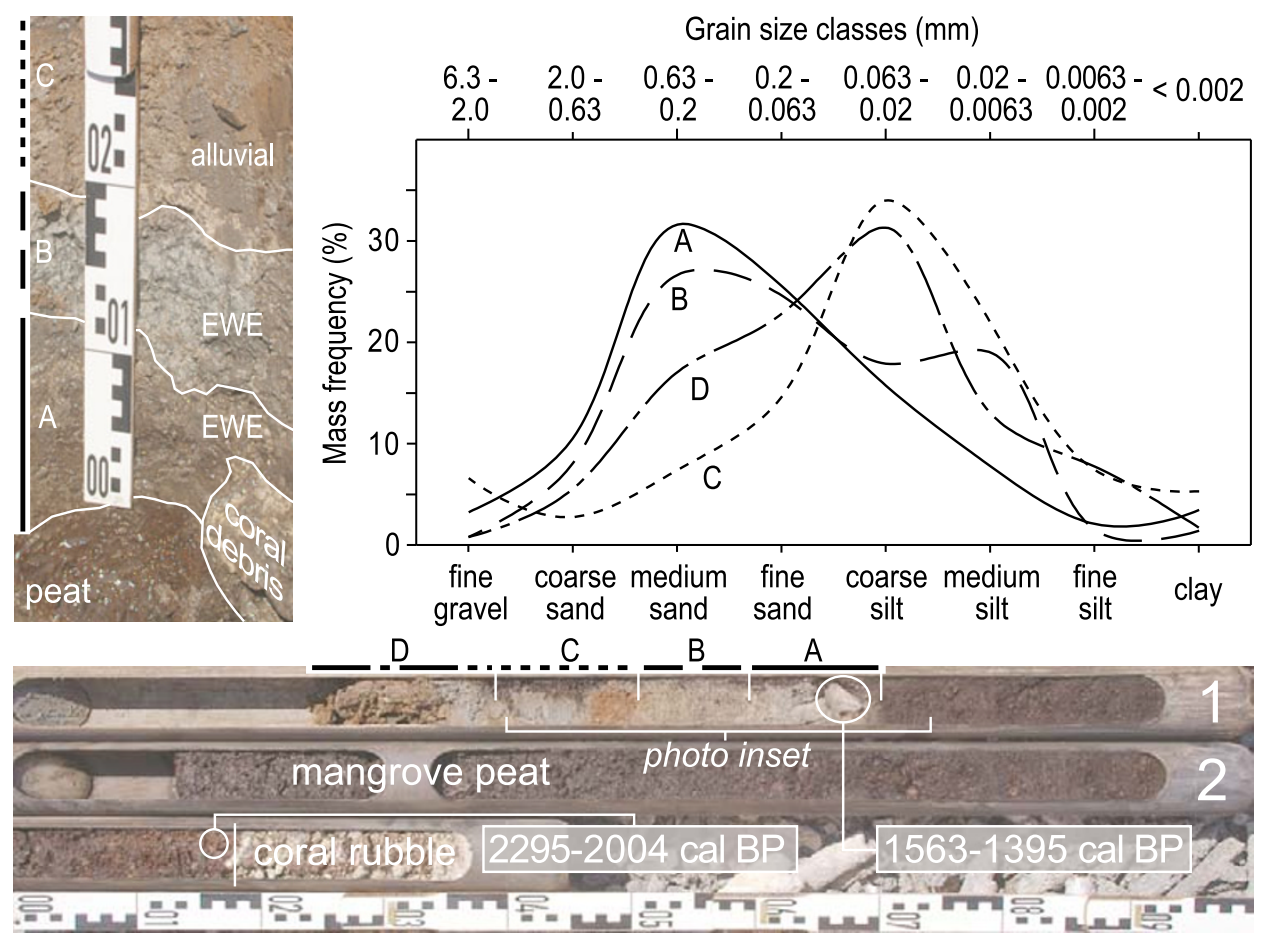

Fig. 9. Sediment core SAT $10(2.45 \mathrm{~m})$ west of Saliña Tam (Fig. 2) with ${ }^{14} \mathrm{C}$ data and grain size distribution of the upper four clastic sediment units. Grain size samples represent the centre of each layer A-D. Each line style indicates a particular grain size distribution of one of the four carbonate sand/mud units (A-D) in the core. Correlating line styles of the core units are displayed on top of the core photo. The photo inset at the top left shows a profile within a trench at the same site, displaying the uppermost part of the peat and three of the overlying carbonate sand/mud units (A-C) as indicated on the core photo as well as a massive coral branch. Correlating line styles are plotted on the left. EWE $=$ extreme wave event.

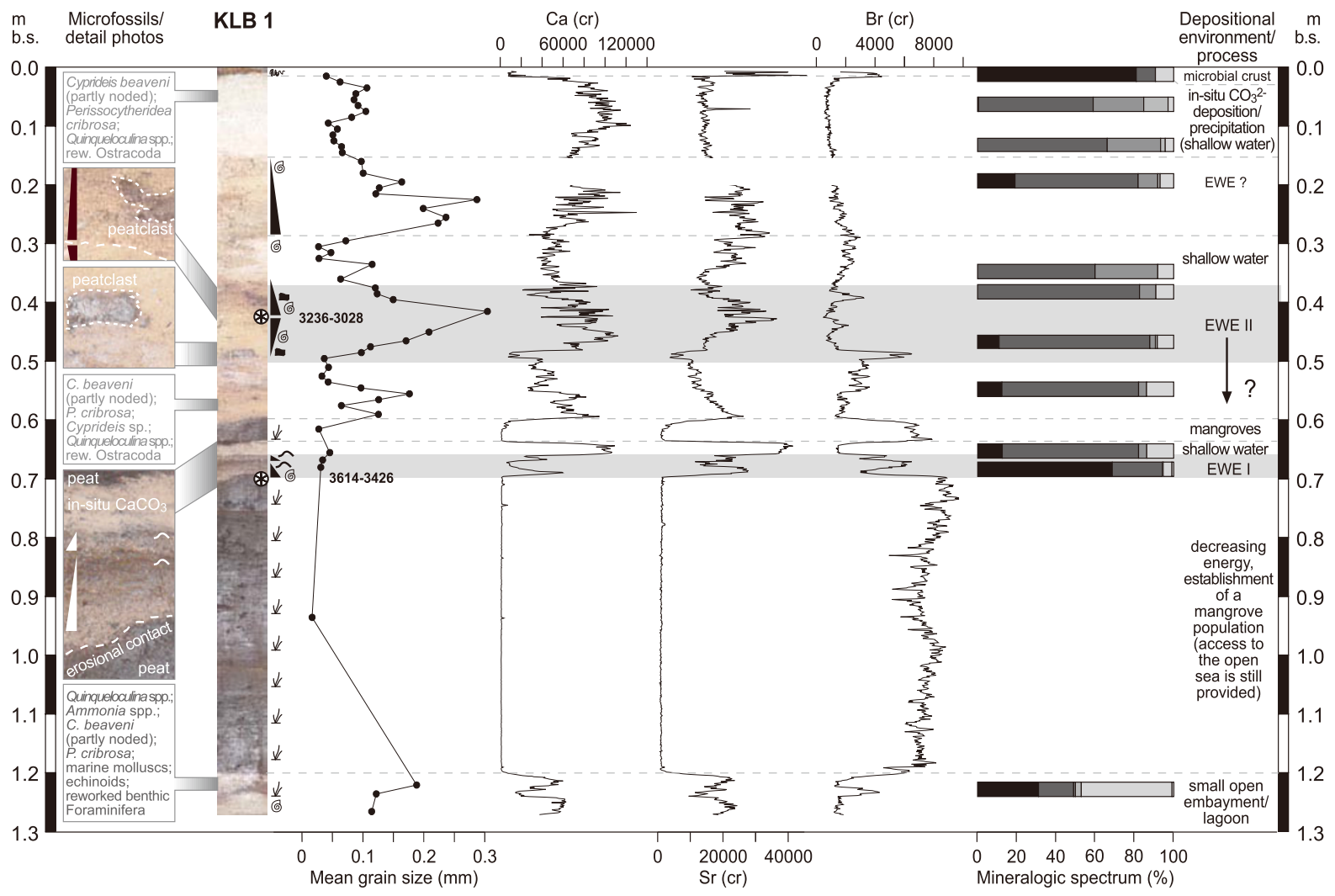

Fig. 10. Push core KLB 1 (Fig. 3) with mean grain size variations, high-resolution XRF data (Ca, Sr, Br; cr = XRF count rates), mineral spectra, microfaunal remains and ${ }^{14} \mathrm{C}$ data $(\mathrm{cal} \mathrm{BP})$. A key is provided in Fig. 5. EWE = extreme wave event. 

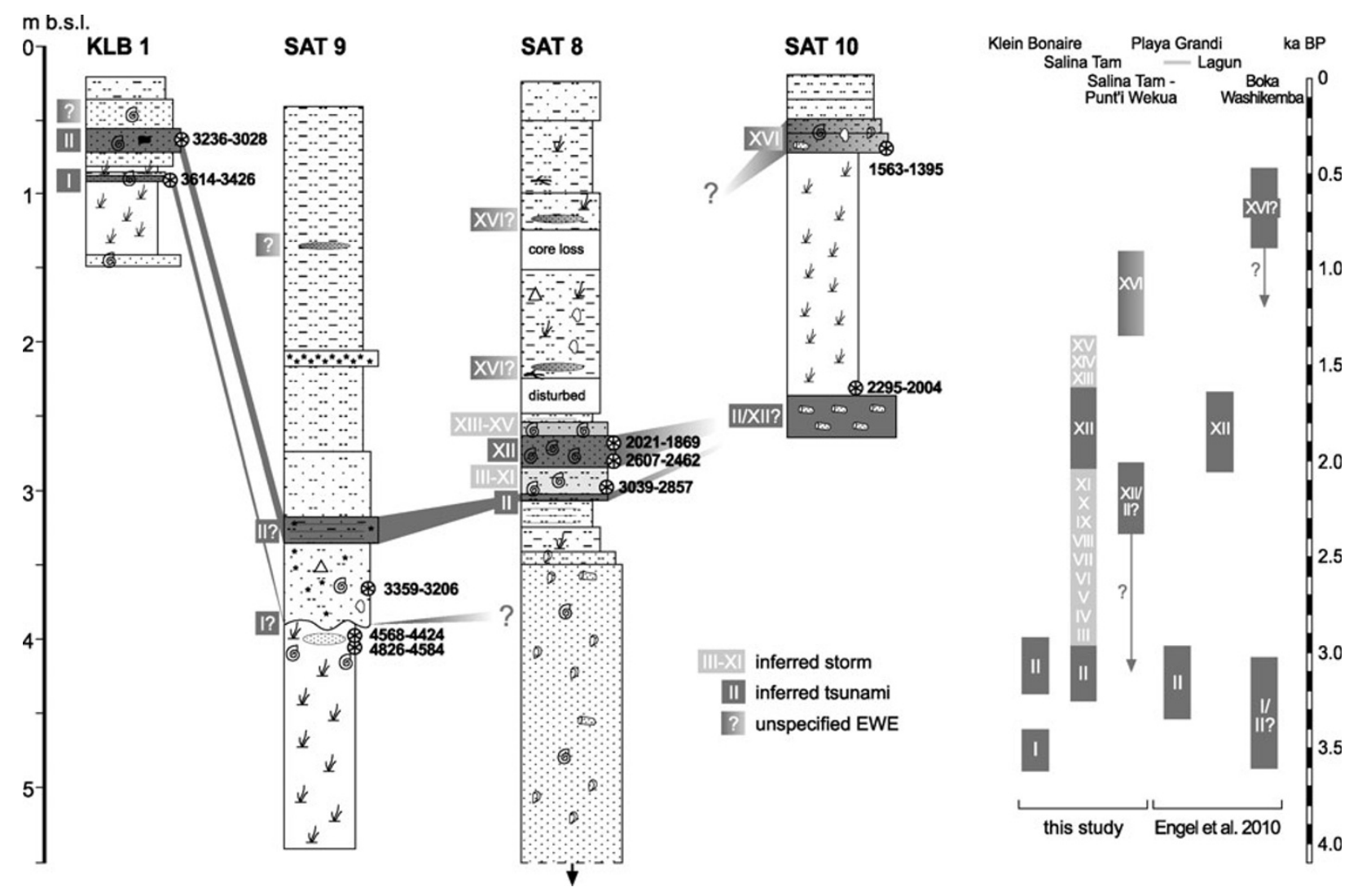

Fig. 11. Left: Synopsis of the cores used in this study including tentative correlations of extreme wave deposits (EWE). Right: Chronology of EWE including the sites of windward Bonaire investigated in Engel et al. (2010). Position and width (time frame) of the EWE is inferred from ${ }^{14} \mathrm{C}$ data which provide either maximum (in case the date derives from an object incorporated into the EWE deposit or from beneath the EWE deposit) or minimum (in case the date derives from the layer above the EWE deposit) ages.

resembling the lower peat is present at $0.64-0.60 \mathrm{~m}$ b.s. A sharp upper boundary separates it from a massive layer of loamy carbonate sand $(0.60-0.35 \mathrm{~m}$ b.s.), which is divided into three subunits: (i) a lowermost normally graded sequence with shells and shell fragments $(0.60-0.50 \mathrm{~m}$ b.s.); (ii) a coarsening-up sequence $(0.50-0.43 \mathrm{~m}$ b.s.) associated with increasing values of $\mathrm{Ca}$ and $\mathrm{Sr}$, a large peatclast, most likely from the underlying peat, and shells of Cerithium sp. in the upper part; (iii) a normally graded bed $(0.43-0.35 \mathrm{~m}$ b.s.) with basal shell material and another large peat clast.

The overlying stratum $(0.35-0.15 \mathrm{~m}$ b.s. $)$ also has a normally graded bed and contains Cerithium sp. shells. At $0.14-0.02 \mathrm{~m}$ b.s. is a pale yellow, silty fine sand consisting of calcite, dolomite, gypsum and halite with no larger components. The surface is composed of a very dark brown aragonite-rich crust.

\section{Discussion}

Interpretation of the cores is based on the assumption that sedimentary patterns are predominantly determined by relative sea level evolution, intermittent river input, typical yearly wave action as well as hurricanes and tsunamis. The frequency of strong hurricanes is considered as periodic (in the order of 10-500 years), the one of major tsunamis as episodic (in the order of 500-5000 years). Both are summarised under the term extreme wave event (EWE). Even though long-term fluctuations in temperature and precipitation were considered to be very important in other palaeoenvironmental investigations along Caribbean shorelines (e.g. Bertran et al., 2004), they appear rather negligible in this study, at least concerning the prehistoric core sections. Evaporation rates throughout the time of deposition seem to have been cosistently high, often resulting in stressful ecological conditions, reflected by the low diversity of the in-situ ostracofauna (cf. Frenzel and Boomer, 2005). Increased sedimentation rates in the last millennium on Bonaire (Engel et al., 2010) may be the result of a combination of anthropogenic impact on the vegetatione.g. livestock breeding since the 16th century AD (Hartog, 1978) - and a regional aridification impulse (Haug et al., 2003).

Subsection 5.1 provides a chronology of coastal evolution and EWEs based on core data. It is separated into evidence from Klein Bonaire (KLB) and Saliña Tam (SAT). The nature of EWEs (tsunami or tropical cyclone) is discussed in 5.2, a synopsis of the cores is shown in Fig. 11.

\subsection{High energy wave impacts and shoreline change}

5.1.1 Klein Bonaire (KLB) In the south of Klein Bonaire, the lowermost calcareous deposit (pre-3.6 ka BP) may be associated with a calm lagoon connected to the open ocean according to the presence of a large number of shallow marine to brackish foraminifers (Quinqueloculina spp., Ammonia spp.) and ostracods ( $C$. beaveni) (e.g. Culver, 1990). Several well-rounded shell fragments point to temporarily intensified energetic conditions. Thus, the mangrove peat overlying this carbonate mud may be inter- 
preted as a regressive process where prograding mangroves colonised marginal marine sediments, similar to findings made by Woodroffe (1981) at North Sound, Grand Cayman.

At around $3.6 \mathrm{ka} \mathrm{BP}$ or later (cerith shell: 3614-3426 cal BP) a high-energy wave event (which we label EWE I) possibly destroyed the mangroves, as indicated by an erosional unconformity and two thin fining-up sequences, each capped by rafted plant fibres from the underlying peat. Ostracod valves from the beds indicate reworking. The event significantly contributed to the formation of a barrier of coral rubble fringing the entire coast of southern Klein Bonaire and which limited access to the open ocean. This is inferred from the subsequent layer of carbonate mud resembling recent deposition at KLB 1. High amounts of dolomite $(>25 \%$ ) within this lithofacies result from increasing $\mathrm{Mg} / \mathrm{Ca}$ ratios due to evaporation of the supratidal sea water and withdrawal of $\mathrm{Ca}$ due to gypsum precipitation and secondary replacement of pre-existing $\mathrm{CaCO}_{3}$ (Deffeyes et al., 1965; Klosowska et al., 2004). Subsequently, mangroves began to recolonise the site.

The mangrove stands, which reestablished at KLB 1 after EWE I, were irreversibly destroyed by a major wave impact (EWE II) overtopping the barrier. EWE II left a deposit, which unconformably overlies the mangrove peat. It is divided into three beds of marine sediment and contains large reworked clasts of the underlying peat material causing excursions in the Br curve (Fig. 9). EWE II struck the coastline of Klein Bonaire 3.2-3.0 ka BP or later (cerith shell: 3236-3028 cal BP).

5.1.2 Saliña Tam (SAT) The deepest and oldest sediment unit reached at Saliña Tam is between 11.00 and $3.25 \mathrm{~m}$ b.s. right behind the barrier of coral rubble (SAT 7/8). High amounts of $\mathrm{Ca}$ and $\mathrm{Sr}$, well rounded carbonate particles and shell debris as well as its extraordinary thickness relate to a sublittoral environment or-regarding the upper part of the unit - to the beach ridge of a shoreline, which ran landward in a sheltered position right at the foot of the MIS 5e cliff (mid-Holocene transgression in Fig. 2). Since long-term littoral sedimentation is connected to the sea level, an age of c. $8 \mathrm{ka}$ for the base of core SAT 8 may be inferred from the model of southern Caribbean sea level evolution by Milne et al. (2005). The early to midHolocene transgression is assumed to have flooded the nearshore parts of the island's drainage network creating bokas with full sea access and a landward fringe of mangroves comparable with today's inlet of Lagun, west Bonaire (cf. Engel et al., 2010). Mangroves established when relative sea level rise decelerated c. 7-6 ka ago (McKee et al., 2007) and compensation through subsurface accumulation of resistant roots and rhizomes was possible (Woodroffe, 1981; McKee et al., 2007). The mangrove populations at Saliña Tam were probably dominated by Rhizophora mangle according to mid-Holocene pollen spectra (Engel et al., 2009) and recent mangrove stands (De Freitas et al., 2005) along the west coast of Bonaire. Small but stable mangrove populations persisting at Saliña Tam until at least $4.5 \mathrm{ka}$ BP are represented by thick fibrous peat accumulations in the landward core SAT 9 (5.00-3.49 m b.s.). Their microfaunal assemblage of brackish ostracods and foraminifers, both of which show relatively high abundance and diversity, as well as numerous juvenile bivalves reflect low-energy environmental conditions of a distal lagoon connected to the open sea.

Isolation of the boka some time before $3000 \mathrm{BP}$ is reflected by thin alternating layers of organic rich sediment, platy aragonite and gypsum, which cover the littoral lithofacies in SAT 8 (Fig. 4). The evaporites relate to autochthonous sedimentation and a negative water balance due to limited water input either from the sea or inland in combination with high evaporation as also observed on Curaçao (Klosowska et al., 2004). Mg, Na, Cl and Ca ions indicate high evaporation rates and isolation from the sea similar to recent conditions, but also continuous sea water supply through the permeable seaward barrier. Depending on fluctuating concentrations of soluble salts, different evaporite types precipitated forming the cyclic laminated depositional pattern. Surface runoff at that time was reduced since the amount of detrital material from the volcanic catchment area (quartz, plagioclase) is very low (SAT 8, 3.00-2.82 $\mathrm{m}$ b.s.). Euryhaline to polyhaline conditions are supported by the sole presence of Cyprideis sp. and Perissocytheridea cribrosa within the ostracofauna (Keyser, 1977).

No sedimentary evidence for an abrupt closure of the boka during an episodic wave event was found at SAT 8. It seems likely that the barrier was formed gradually due to the low rate of sea-level rise (Milne et al., 2005), a moderate longshore current from south to northwest (Zonneveld et al., 1977) and the effects of periodic tropical cyclones, which are capable of moving coral rubble onshore (Schubert and Valastro, 1976; Scheffers and Scheffers, 2006; Spiske and Jaffe, 2009). The stratigraphy of the lower part of the barrier (Fig. 5) also supports a gradual closure of Saliña Tam due to the very well rounded particles in its entire lower part (pre-1300 BP according to Scheffers et al., 2009) resembling the degree of roundness of A. cervicornis fragments at the present beachface. They differ significantly from the angular coral rubble, which builds up the uppermost part of the barrier (Fig. 3) and was removed and transported onshore by a major hurricane (EWE XVI or later?) according to Scheffers (2005) and Scheffers et al. (2009). For the period when Saliña Tam closed (c. 3.5-3.4 ka BP), a gradual barrier formation was also reconstructed for the St. Michiel Lagoon at leeward Curaçao, which shares similar morphodynamic boundary conditions (Klosowska et al., 2004). However, the isolation of Saliña Tam is in the same time window as EWE I (inferred from the core at Klein Bonaire) which may have accumulated coral material at the outlet of the boka.

Isolation of the small basin of Saliña Tam resulted in a demise of the mangrove population in the landward part of Saliña Tam (SAT 9), which depends on the circulation of sea water. The deposition of autochthonous carbonate mud at SAT 9 started before 3359-3206 cal BP and correlates with the evaporite facies in SAT 8 (3.00-2.82 m b.s., pre3039-2857 cal BP). The carbonate mud itself in SAT 9 is not related to an EWE since it is very homogeneous and marine sand, faunal remains or reworked material of the underlying peat are absent. However, the erosional unconformity might be induced by purely erosional processes during 
EWE I-the relevance of which has been demonstrated by MacInnes et al. (2009) on the Kurils, N Pacific. The abundant valves of noded $C$. beaveni $(75 \%)$ and $P$. cribrosa as well as several miliolinid foraminifers within the carbonate mud indicate euryhaline to polyhaline still water conditions (Keyser, 1977) and show no signs of reworking.

We interpret the basal part of the coarse shelly sequence in SAT 8 (2.82-2.76) to be a deposit of EWE II (cf. KLB 1 , chapter 5.1.1); the age control is from an overlying bed (2.72 m b.s.) of 3039-2857 cal BP. This basal unit is a fining-up sequence, which has a partly marine microfauna, an upward decrease in $\mathrm{Ca}$ and $\mathrm{Sr}$, and is capped by organicrich mud. The mud layer, marked by a small $\mathrm{Br}$ peak (Fig. 6), we interpret to have been deposited after flow attenuation.

We also interpret the following nine sequences (2.76$2.60 \mathrm{~m}$ b.s. in Fig. 6) as deposits of overwash events (EWE III-XI) affecting the interior of Saliña Tam due to the partial destruction of the barrier during EWE II. Within the entire section EWE III-XI, increased marine influence is reflected by abraded sand-sized shell particles. Each of the nine depositional cycles comprises basal sand with increasing phytomass and mud content upward. Accordingly, nine significant overwash events may be inferred between c. $3.0 \mathrm{ka}$ BP and the overlying age $2.0-1.8 \mathrm{ka} \mathrm{BP}$ based on radiocarbon dates of cerith shells (Table 1, Fig. 5).

The depositional sequence containing a radiocarbon age of 2021-1869 cal BP unconformably overlies the EWE III$\mathrm{XI}$ unit and consists of a wide variety of marine microfossils (benthic and planktonic) indicating that it was generated by a larger EWE (which we label XII) than EWE III-XI.

After EWE XII, three minor overwash deposits separated by relatively thick mud sections (EWE XIII-XV) indicate a lower frequency compared to the phase of EWE III-XI.

Above the EWE sequences associated with a partial destruction of the barrier and a higher susceptibility to overwash deposition, still-water conditions very similar to the period before EWE II (pre-3.2-3.0 ka BP) indicate that the barrier closing the boka recovered. We assume that reshaping the barrier represents development towards an equilibrium defined as "stability of form" (Woodroffe, 2002: 32) during a relatively stable sea level after disturbances (EWE II-XII) manifested by cyclic carbonate sequences spanning a period of c. $1 \mathrm{ka}$. This is a long time given the fact that beaches of Sumatra and Thailand have reorganised only a few years after the Indian Ocean Tsunami of 2004 (IOT) (Choowong et al., 2009; Liew et al., 2010). Nevertheless, Kraus (2005: 171) describes barrier breachings, which did "not recover on the timescale of human lifetime" in case the event was so strong that the sediment was transported into deeper water-consider the narrow reef and steep offshore slope of Bonaire-where it was out of reach for longterm wave action. Temporary changes in external boundary conditions, e.g. an interruption of the longshore current, increased hurricane frequency, and limited sediment sources, also have to be taken into consideration. In addition to the coring results, the reestablishment of the barrier after $2.0 \mathrm{ka}$ BP is corroborated by ESR ages from the Saliña Tam barrier, all of which are younger than $1.3 \mathrm{ka}$ (Scheffers, 2005).

The period of increased susceptibility to overwash impact at Saliña Tam (EWE III-XI) or EWE II both inferred from SAT 8, might correlate with layer 2.94-2.77 m b.s. in SAT 9 where reworked ostracods were identified; however, this is a tenuous assumption since age control is not available. Apart from that, SAT 9 has no clear event deposits.

West of Saliña Tam, at SAT 10, a mangrove population established around $2.0 \mathrm{ka} \mathrm{BP}$. Below the mangrove peat, the coral rubble from the basal core unit is interpreted to derive from a major EWE (II or XII?). After the event, the area was sheltered by the coastal barrier but still had access to the sea providing a suitable habitat for mangroves. The demise of the mangroves is associated with the two overlying units of medium sand (layers A and B in Fig. 9), which most probably represent one or two EWE. The age of a coral boulder found at the landward foot of the broad ridge of coral rubble adjacent to SAT 10 was dated to $1300 \pm 60$ (Fig. 2; Scheffers, 2005). Since a Diploria sp. fragment from the sand layer yielded a similar age (1563-1395 cal BP), boulder transport and deposition of the sand layers may be linked to one EWE (which we label XVI). The overlying silt-dominated alluvial lithofacies (C and D in Fig. 9) contains several carbonate sand components testifying to periodic small overwash processes.

The upper sediment column of SAT 8 (2.00-0.00 m b.s.) and SAT 9 (2.78-0.00 $\mathrm{m}$ b.s.) is dominated by detrital sedimentation as indicated by increased amounts of quartz, anorthite and albite (feldspar varieties) in the mineralogical spectrum. Mean grain size is small reflecting the interface between the fluctuating still water body and distal alluvial fans (inferred from changing LOI percentages). At SAT 8 , two candidate overwash deposits occur at 1.96-1.87 m b.s., where several bryozoan fragments are preserved, and at $0.97-0.77 \mathrm{~m}$ b.s. (EWE XVI?). The upper one might correlate with a peak in $\mathrm{CaCO}_{3}$ at SAT 9 (1.00-0.90 m b.s.). However, both layers are heavily altered by capillary evaporites from interstitial pore waters.

\subsection{Extreme wave events (EWE): tsunamis or tropical cyclones?}

Sediment layers from Saliña Tam and Klein Bonaire interpreted as extreme wave deposits fulfill several criteria commonly associated with tsunami and/or storm wave impacts, such as a basal unconformity, reworked underlying material, graded bedding, increased mean grain size, peaks in marine indicator ions $(\mathrm{Ca}, \mathrm{Sr})$, increased $\mathrm{CaCO}_{3}$ content as well as marine microfossils showing signs of reworking (Switzer and Jones, 2008; Mamo et al., 2009; Peters and Jaffe, 2010). However, in the sedimentary record, differentiating between deposits of tsunamis and waves generated by extraordinary storms is challenging (Bridge, 2008) since most onshore sedimentary features attributed to either one may be generated by both hydrodynamic processes (Sugawara et al., 2008). Further problems in deducing a chronology of extreme wave events from the stratigraphic record include the possibility that events may not leave sedimentary traces, that sediments may be eroded or heavily disturbed, e.g. by bioturbation (Szczuciński, 2012), and that radiometric ages obtained from the deposit may not represent the age of the event (Sugawara et al., 2008) due to possible previous reworking or local reservoir ages. The sedimentary pattern a tsunami creates is hard to predict 
and site-specific. However, interpretations may be enhanced by identifying the presence of a high number of common tsunami signature types, by careful analyses of the local sedimentary environment and "the geologic potential for tsunamis" (triggering processes) at a site (Peters and Jaffe, 2010: 22), by comparing a candidate tsunami deposit with local modern analogues (either recent tsunami or storm deposits), and by also considering the coarse-clast record (e.g. Yu et al., 2009; Peters and Jaffe, 2010). On Bonaire, no historical tsunamis are documented, but category 5 hurricanes passed the island several times within close distance during the recent past (Meteorological Service of the Netherlands Antilles and Aruba, 2009) leaving very little to no sediment at coastal depressions such as alluvial plains and bokas (Engel et al., 2010).

5.2.1 EWE I $(\rightarrow$ KLB 1) Tsunami. EWE I was only found in KLB 1 where it is represented by two thin graded beds of 2 and $1 \mathrm{~cm}$ thickness. It may also be associated with an erosional unconformity above the peat in SAT 9. The graded beds are dated to c. $3.6 \mathrm{ka} \mathrm{BP}$ or later (Fig. 11). Both graded beds are characterized by plant remains and finer material covering basal marine sand. These findings indicate a long wave period of at least several minutes of flow attenuation. Similar observations were made following the tsunamis of Papua New Guinea 1998, Peru 2001 (Morton et al., 2007) and the IOT 2004 (Choowong et al., 2008; Naruse et al., 2010). Thus, storm wave origin after a long period of undisturbed mangrove growth seems unlikely though not impossible.

5.2.2 EWE II $(\rightarrow$ SAT 8, KLB 1) Tsunami. Barrier destruction or breaching by EWE II at Saliña Tam c. 3.2-3.0 $\mathrm{ka} \mathrm{BP}$ is a phenomenon commonly associated with extraordinary storms or tsunamis (Andrade et al., 2004; Kortekaas and Dawson, 2007; Atwater et al., 2010). Even though it is difficult to deduce the exact origin of the EWE II deposit in SAT 8, the presence of open marine planktonic formanifera, which are absent in the overlying deposits from periodic events may point to tsunami (cf. Luque et al., 2002; Uchida et al., 2010). At Klein Bonaire, two normally and one inversely graded sequence are associated with EWE II. Large intraclasts of the underlying peat are a typical feature of tsunami deposits (Kortekaas and Dawson, 2007; Morton et al., 2007; Choowong et al., 2008; Switzer and Jones, 2008; Bourgeois, 2009; Mamo et al., 2009; Peters and Jaffe, 2010), even though they have also been observed within storm deposits (Wang and Horwitz, 2007). At Playa Grandi, northeast Bonaire, a coeval deposit was interpreted as tsunamigenic based on taphonomic characteristics and the comparison with the marginal sediment input during recent hurricanes (Engel et al., 2010). Scheffers et al. (2009) deduced a major tsunami around $3.1 \mathrm{ka}$ BP based on ${ }^{14} \mathrm{C}$ and ESR ages of onshore coral debris from eastern Bonaire even though this chronological interpretation has recently been challenged by Morton et al. (2008).

5.2.3 EWE III-XI $(\rightarrow$ SAT 8) Cyclones. Depositional cycles of sand and organic-rich mud present in SAT 8 relate to periodically recurring inundation pulses during EWE III-XI in the order of decades to centuries. The lower sequences might also be associated with a tsunami wave train of EWE II creating several fining-up layers (cf. Morton et al., 2007; Switzer and Jones, 2008).

However, nine (EWE III-XI) thin graded sequences implying c. $1 \mathrm{ka}$ of deposition correspond to the approximate recurrence rate of severe tropical cyclones on Bonaire, which is about 100 years (Meteorological Service of the Netherlands Antilles and Aruba, 2009). It is assumed that storm waves transported reworked particles from the surf zone and shallow marine ostracods into the partly opened southern section of Saliña Tam, each time followed by ponding conditions resulting in sedimentation of organicrich mud and plant debris and growth of algae (cf. Morton, 1978). This interpretation is in accordance with that of sand layers in a hypersaline lagoon of southern Puerto Rico by Donnelly and Woodruff (2007). A series of thin normally graded sequences may only be attributed to one single storm event if the graded layers are not separated by mud layers due to the short periods of storm wave pulses (Morton et $a l ., 2007)$. No planktonic or larger foraminifera were identified in these beds, also indicating a different, less extended source area of the sand than in the sediments of EWE II and XII.

5.2.4 EWE XII $(\rightarrow$ SAT 8, SAT $10[$ ? ] $)$ Tsunami. Around 2.0-1.8 ka BP, EWE XII struck Bonaire's coastline. For the same time, a tsunami impact was inferred from a massive shell debris layer on the eastern shore (Engel et al., 2010). The high diversity of marine particles including planktonic foraminifers and marine ostracods recorded in this bed at SAT 8 (Fig. 5) indicates a wider source area compared to the underlying beds interpreted as storm deposits and may support the tsunami hypothesis. Larger foraminifers such as Amphistegina sp., for instance, relating to a reefal sediment source were also found in deposits of the IOT 2004 on the Andaman Islands (Hussain et al., 2006). In a sediment sequence from Martinhal (Algarve, Portugal) containing deposits from the 1755 AD Lisbon tsunami and subsequent storm events, slightly increased microfossil diversity within the tsunami sediments was one of the few features differentiating the layers (Kortekaas and Dawson, 2007). The bedding structure including shell debris at the bottom, two fining-up sequences followed by inverse grading and a relatively thick normally graded sublayer may correspond to tsunamigenic deposition rather than to cyclone-induced waves (Morton et al., 2007).

5.2.5 EWE XIII-XV $(\rightarrow$ SAT 8) Cyclones. Sediment layers of EWE XII-XV (SAT 8) show a similar structure to those of EWE III-XI, even though thicker subunits of organic-rich mud indicate lower frequency, which could be related to barrier regrowth. Cyclic hurricane impacts are assumed to be responsible for their deposition since diversity and abundance of marine microfossils decreases compared to EWE XII.

5.2.6 EWE XVI $(\rightarrow$ SAT 10, SAT 8 [?]) Tsunami? A sand deposit unconformably overlying mangrove peat at SAT 10, containing shell debris and coral rubble (15631395 cal BP), and an adjacent ESR-dated coral boulder (1300 \pm 60 a according to Scheffers, 2005) indicate that around $1.3 \mathrm{ka} \mathrm{BP}$ or later, a major wave event (EWE XVI) impacted the leeward shore of Bonaire. EWE XVI is the youngest EWE that is well-preserved in the local stratigraphy. Major historical hurricanes, e.g. in 1877 and 1999, 
only modified the higher berm (Scheffers, 2005; Fig. 2), but did not leave distinct sand sheets within the back-barrier, what may indicate that EWE XVI was a tsunami.

\section{Conclusion}

The stratigraphy of Saliña Tam at the leeward coast of Bonaire reflects an interplay of long-term sea-level rise, gradual sediment dynamics as well as periodic (tropical cyclones) and episodic (tsunamis) wave impacts. Figure 11 provides a synopsis of the cores of this study focussing on the distribution of extreme wave deposits. Clear sedimentary evidence for EWE I (tsunami) is only provided on Klein Bonaire, though it may be associated with the erosional unconformity in SAT 9. The scale on the right on Fig. 11 shows that EWE II (around 3.2-3.0 ka BP) which we also interpret as tsunamigenic is well represented at several sites on the island including the windward coast. A third candidate tsunami deposit (EWE XII) from c. 2.0$1.8 \mathrm{ka} \mathrm{BP}$ is preserved at Saliña Tam (SAT 8) and Lagun (Engel et al., 2010). EWE XVI (post-1.3 ka BP) had a major impact on barrier accumulation at Saliña Tam. It may also correspond to a tsunami since recent strong hurricanes (e.g. west-east-tracking Hurricane Lenny in 1999) caused no changes on the top and back of the barrier. However, sedimentary evidence of this event is limited at other sites. Today, i.e. in case of a stable barrier of coral rubble, marine sediment deposition at Saliña Tam tends to zero during tropical cyclone conditions. Thus, the graded sequences of EWE III-XI and XIII-XV, which we interpret as storm wave deposits, are associated with a breach of the barrier.

The geographical distribution of event deposits was found to be very irregular and difficult to predict, even on a small spatial scale. The same applies to the impact of tsunamis and extraordinary storms on the coastal morphology. However, the outcome of this study is that high-energy wave events do have long-lasting effects on the coastal morphology and ecosystem of Bonaire. This influence includes century-scale destruction of coastal ridges and may even trigger or drive ridge formation (cf. Scheffers, 2005; Scheffers et al., 2009). This process has recently been observed during Hurricane Lenny, when a spit of coral rubble (c. $100 \mathrm{~m}$ long) was accumulated in the foreshore of north Bonaire (Scheffers and Scheffers, 2006; Morton et al., 2008). EWEs seem to control the formation of coastal sedimentary landforms to a certain extent, as already been emphasised by Scheffers (2004, 2005), Morton et al. (2008), Scheffers et al. (2009), and Watt et al. (2010), and thus, they shift ecological and morphodynamic boundary conditions of the circumlittoral bokas.

Acknowledgments. Funding by the Deutsche Forschungsgemeinschaft (German Research Foundation) is gratefully acknowledged (BR 877/26-1). Administrative and logistic support was kindly provided by DROB (Government of the Island Territory Bonaire/Department of Environment and Natural Resources) and STINAPA (Bonaire National Parks Foundation). We are thankful for fieldwork support by Frank Schäbitz (Cologne), Timo Willershäuser (Mainz) and Jan Brouwer (Hato, Bonaire). Andreas Ginau (Frankfurt/M.) helped with the interpretation of XRD spectra. Andreas Bolten (Cologne) calculated the bathymetric model. Armine Shahnazarian (Cologne) assisted the XRF analyses. We are grateful to Jody Bourgeois (Seattle) and Klaus Re- icherter (Aachen) for their thorough reviews and helpful remarks as well as Kirstin Jacobson (Marburg) for language editing.

\section{References}

Andrade, C., M. C. Freitas, J. Moreno, and S. C. Craveiro, Stratigraphical evidence of Late Holocene barrier breaching and extreme storms in lagoonal sediments of Ria Formosa, Algarve, Portugal, Mar. Geol., 210, 339-362, 2004.

Arbeitsgemeinschaft Boden, Bodenkundliche Kartieranleitung, 438 pp., Schweizerbart, Stuttgart, 2005 (in German).

Atwater, B. F., U. S. ten Brink, M. Buckley, R. S. Halley, B. E. Jaffe, A. M. López-Venegas, E. G. Reinhardt, M. P. Tuttle, S. Watt, and Y. Wei, Geomorphic and stratigraphic evidence for an unusual tsunami or storm a few centuries ago at Anegada, British Virgin Islands, Nat. Haz., doi:10.1007/s11069-010-9622-6, 2010.

Audemard, F. A., G. Romero, H. Rendon, and V. Cano, Quaternary fault kinematics and stress tensors along the southern Caribbean from fault slip data and focal mechanism solutions, Earth Sci. Rev., 69, 181-233, 2005.

Beck, R., D. Burger, and K.-H. Pfeffer, Laborskript, Kl. Arb. Geogr. Inst. Univ. Tübingen, 11, 215 pp., 1993 (in German).

Bertran, P., D. Bonnissent, D. Imbert, P. Lozouet, N. Serrand, and C. Stouvenot, Paléoclimat des Petit Antilles depuis 4000 ans BP: l'enregistrement de la lagune de Grand-Case à Saint-Martin, C. R. Geosci., 336, 1501-1510, 2004 (in French with abridged English version).

Blott, S. J. and K. Pye, GRADISTAT: A grain size distribution and statistics package for the analysis of unconsolidated sediments, Earth Surf. Proc. Land., 26, 1237-1248, 2001.

Bourgeois, J., Geologic effects and records of tsunamis, in The Sea, Volume 15: Tsunamis, edited by A. R. Robinson and E. N. Bernard, pp. 53-91, Harvard University Press, 2009.

Bridge, J. S., Discussion of articles in "Sedimentary features of tsunami deposits", Sediment. Geol., 211, 94, 2008.

Bries, J. M., A. O. Debrot, and D. L. Meyer, Damage to the leeward reefs of Curaçao and Bonaire, Netherlands Antilles from a rare storm event: Hurricane Lenny, November 1999, Coral Reefs, 23, 297-307, 2004.

Chagué-Goff, C., S. Dawson, J. R. Goff, J. Zachariasen, K. R. Berryman, D. L. Garnett, H. M. Waldron, and D. C. Mildenhall, A tsunami (ca. 6300 years BP) and other Holocene environmental changes, northern Hawke's Bay, New Zealand, Sediment. Geol., 150, 89-102, 2002.

Choowong, M., N. Murakoshi, K. Hisada, T. Charoentitirat, P. Charusiri, S. Phantuwongraj, P. Wongkok, A. Choowong, R. Subsayjun, V. Chutakositkanon, K. Jankaew, and P. Kanjanapayont, Flow conditions of the 2004 Indian Ocean tsunami in Thailand inferred from capping bedforms and sedimentary structures, Terra Nova, 20, 141-149, 2008.

Choowong, M., S. Phantuwongraj, T. Charoentitirat, V. Chutakositkanon, S. Yumuang, and P. Charusiri, Beach recovery after 2004 Indian Ocean tsunami from Phang-nga, Thailand, Geomorphology, 104, 134-142, 2009.

Croudace, I. W., A. Rindby, and R. G. Rothwell, ITRAX: description and evaluation of a new multi-function X-ray core scanner, in New Techniques in Sediment Core Analysis, edited by R. G. Rothwell, Geol. Soc. Lond. Spec. Publ., 267, 51-63, 2006.

Culver, S. J., Benthic Foraminifera of Puerto Rican mangrove-lagoon systems: Potential for palaeoenvironmental interpretations, Palaios, 5, 34$51,1990$.

De Buisonjé, P. H., Neogene and Quaternary Geology of Aruba, Curaçao and Bonaire, $\mathrm{PhD}$ thesis, Universiteit van Amsterdam, The Netherlands, 1974.

De Freitas, J. A., B. S. J. Nijhof, A. C. Rojer, and A. O. Debrot, Landscape ecological vegetation map of the Island of Bonaire (Southern Caribbean), Royal Netherlands Academy of Arts and Sciences, Amsterdam, (www.knaw.nl/publicaties/pdf/20031055.pdf), last access: 1201-2010, 2005.

Deffeyes, K. S., F. J. Lucia, and P. K. Weyl, Dolomitization of recent and Plio-Pleistocene sediments by marine evaporate waters on Bonaire, Netherlands Antilles, in Dolomitization and Limestone Diagenesis, edited by L. C. Pray and R. C. Murray, SEPM Spec. Publ., 13, 71-88, 1965.

Deplus, C., A. Le Friant, C. Boudon, J.-C. Komorowski, B. Villemant, C. Harford, J. Ségoufin, and J.-L. Cheminée, Submarine evidence for large-scale debris avalanches in the Lesser Antilles Arc, Earth Planet. Sci. Lett., 192, 145-157, 2001.

Donnelly, J. P. and J. D. Woodruff, Intense hurricane activity over the 
past 5,000 years controlled by El Niño and the West African monsoon, Nature, 447, 465-468, 2007.

Engel, M., A. Bolten, H. Brückner, G. Daut, D. Kelletat, F. Schäbitz, A. Scheffers, S. R. Scheffers, A. Vött, M. Wille, and T. Willershäuser, Reading the chapter of extreme wave events in nearshore geo-bioarchives of Bonaire (Netherlands Antilles)_initial results from Lagun and Boka Bartol, Marburg. Geogr. Schr., 145, 157-178, 2009.

Engel, M., H. Brückner, V. Wennrich, A. Scheffers, D. Kelletat, A. Vött, F. Schäbitz, G. Daut, T. Willershäuser, and S. M. May, Coastal stratigraphies of eastern Bonaire (Netherlands Antilles): new insights into the palaeotsunami history of the southern Caribbean, Sediment. Geol., 231, 14-30, 2010

Focke, J. W., Holocene development of coral fringing reefs, leeward off Curaçao and Bonaire (Netherlands Antilles), Mar. Geol., 28, M31-M41, 1978.

Folk, R. L. and W. C. Ward, Brazos River Bar: a study in the significance of grain size parameters, J. Sediment. Petrol., 27, 3-26, 1957.

Frenzel, P. and I. Boomer, The use of ostracods from marginal marine, brackish waters as bioindicators of modern and Quaternary environmental change, Palaeogeogr. Palaeoclimatol. Palaeoecol., 225, 68-92, 2005 .

Grindlay, N. R., M. Hearne, and P. Mann, High risk of tsunami in the Northern Caribbean, Eos, 86(12), 121, 126, 2005.

Hartog, J., A Short History of Bonaire, 118 pp., De Wit, Aruba, 1978

Haug, G. H., D. Günther, L. C. Peterson, D. M. Sigman, K. Hughen, and B. Aeschlimann, Climate and the collapse of Maya civilization, Science, 299, 1731-1735, 2003.

Herweijer, J. P. and J. W. Focke, Late Pleistocene depositional and denudational history of Aruba, Bonaire and Curaçao (Netherlands Antilles), Geol. Mijnbouw, 57(2), 177-187, 1978.

Hornbach, M. J., P. Mann, F. W. Taylor, and S. W. Bowen, Estimating the age of near-shore carbonate slides using coral reefs and erosional markers: A case study from Curaçao, Netherlands Antilles, Sediment. Rec., 8(1), 4-10, 2010.

Hussain, S. M., R. Krishnamurthy, M. Suresh Gandhi, K. Ilayaraja, P. Ganesan, and S. P. Mohan, Micropalaeontological investigations on tsunamigenic sediments of Andaman Islands, Curr. Sci., 91(12), 1655$1667,2006$.

Jones, B. and I. G. Hunter, Very large boulders on the coast of Grand Cayman: The effects of giant waves on Rocky Coastlines, J. Coast. Res., 8(4), 763-774, 1992.

Kelletat, D., A. Scheffers, and S. Scheffers, Holocene tsunami deposits on the Bahaman island of Long Island and Eleuthera, Z. Geomorphol., 48(4), 519-540, 2005.

Keyser, D., Ecology and zoogeography of recent brackish-water Ostracoda (Crustacea) from South-West Florida, in Aspects of Ecology and Zoogeography of Recent and Fossil Ostracoda, edited by H. Löffler, pp. 207-222, Kluwer Academic Publishers, The Hague, 1977.

Khan, S., E. Robinson, D.-A. Rowe, and R. Coutou, Size and mass of shoreline boulders moved and emplaced by recent hurricanes, Jamaica, Z. Geomorphol., 54(Suppl. 3), 281-299, 2010.

Klosowska, B. B., S. R. Troelstra, J. E. van Hinte, D. Beets, K. van der Borg, and A. F. M. de Jong, Late Holocene environmental reconstruction of St. Michiel saline lagoon, Curaçao (Dutch Antilles), Radiocarbon, 46(2), 765-774, 2004.

Kobluk, D. R. and D. R. Crawford, A modern hypersaline organic mudand gypsum-dominated basin and associated microbialites, Palaios, 5(2), 134-148, 1990

Köhn, M., Bemerkungen zur mechanischen Bodenanalyse. III. Ein neuer Pipettierapparat, J. Plant. Nutr. Soil Sc., 11(1), 50-54, 1928 (in German).

Kortekaas, S. and A. G. Dawson, Distinguishing tsunami and storm deposits: An example from Martinhal, SW Portugal, Sediment. Geol., 200, 208-221, 2007.

Kraus, N. C., Beach Profile, in Encyclopedia of Coastal Science, edited by M. Schwartz, pp. 169-172, Springer, Dordrecht, 2005.

Liew, S. C., A. Gupta, P. P. Wong, and L. K. Kwoh, Recovery from a large tsunami mapped over time: the Aceh coast, Sumatra, Geomorphology, 114, 520-529, 2010.

Luque, L., J. Lario, J. Civis, P. G. Silva, C. Zazo, J. L. Goy, and C. J. Dabrio, Sedimentary record of a tsunami during Roman time, Bay of Cadiz, Spain, J. Quaternary Sci., 17, 623-631, 2002.

MacInnes, B. T., J. Bourgeois, T. Pinegina, and E. A. Kravchunovskaya, Tsunami geomorphology: Erosion and deposition from the 15 November 2006 Kuril Island tsunami, Geology, 37, 995-998, 2009.

Mamo, B., L. Strotz, and D. Dominey-Howes, Tsunami sediments and their foraminiferal assemblages, Earth-Sci. Rev., 96, 263-278, 2009. Mattioli, G. S., B. Voight, A. T. Linde, I. S. Sacks, P. Watts, C. Widiwijayanti, S. R. Young, D. Hidayat, D. Elsworth, P. E. Malin, E. Shalev, E. Van Boskirk, W. Johnston, R. S. J. Sparks, J. Neuberg, V. Bass, P. Dunkley, R. Herd, T. Syers, P. Williams, and D. Williams, Unique and remarkable dilatometer measurements of pyroclastic flow-generated tsunamis, Geology, 35(1), 25-28, 2007.

McKee, K. L., D. R. Cahoon, and I. C. Feller, Caribbean mangroves adjust to rising sea level through biotic controls on change in soil elevation, Global Ecol. Biogeogr., 16, 545-556, 2007.

Meteorological Service of the Netherlands Antilles and Aruba, Hurricanes and Tropical Storms in the Netherlands Antilles and Aruba (URL: http://www.meteo.an/include/HurricanesandTropicalStorms.pdf), last access: 09-27-2010, 2009.

Milne, G. A., A. J. Long, and S. E. Bassett, Modelling Holocene relative sea-level observations from the Caribbean and South America, Quaternary Sci. Rev., 24, 1183-1202, 2005.

Morton, R. A., Large-scale rhomboid bed forms and sedimentary structures associated with hurricane washover, Sedimentology, 25, 183-204, 1978.

Morton, R. A., G. Gelfenbaum, and B. E. Jaffe, Physical criteria for distinguishing sandy tsunami and storm deposits using modern examples, Sediment. Geol., 200, 184-207, 2007.

Morton, R. A., B. M. Richmond, B. E. Jaffe, and G. Gelfenbaum, Coarseclast ridge complexes of the Caribbean: A preliminary basis for distinguishing tsunami and storm-wave origins, J. Sediment. Res., 78, 624637, 2008.

Naruse, H., S. Fujino, A. Suphawajruksakul, and T. Jarupongsakul, Features and formation processes of multiple deposition layers from the 2004 Indian Ocean Tsunami at Ban Nam Kem, southern Thailand, Island Arc, 19, 399-411, 2010.

O'Loughlin, K. F. and J. F. Lander, Caribbean Tsunamis-A 500-Year History from 1498-1998, 280 pp., Kluwer Academic Publishers, Dordrecht, 2003.

Pérez, L., R. Bugja, J. Massaferro, P. Steeb, R. van Geldern, P. Frenzel, M. Brenner, B. Scharf, and A. Schwalb, Post-Columbian environmental history of Lago Petén Itzá, Guatemala, Rev. Mex. Cienc. Geol., 27, 490 507, 2010.

Peters, R. and B. Jaffe, Identification of tsunami deposits in the geologic record: Developing criteria using recent tsunami deposits, USGS OpenFile Report, 2010-1239, 43 pp., 2010.

Pijpers, P. J., Geology and paleontology of Bonaire (D.W.I.), Geographische en Geologische Mededeelingen. Physiographisch-Geologische Reeks, 8, 103 pp., 1933.

Radtke, U., G. Schellmann, A. Scheffers, D. Kelletat, B. Kromer, and H. U. Kasper, Electron spin resonance and radiocarbon dating of coral deposited by Holocene tsunami events on Curaçao, Bonaire and Aruba (Netherlands Antilles), Quatern. Sci. Rev., 22, 1309-1315, 2003.

Reimer, P. J., M. G. L. Baillie, E. Bard, A. Bayliss, J. W. Beck, P. G Blackwell, C. Bronk Ramsey, C. E. Buck, G. S. Burr, R. L. Edwards, M. Friedrich, P. M. Grootes, T. P. Guilderson, I. Hajdas, T. J. Heaton, A. G. Hogg, K. A. Hughen, K. F. Kaiser, B. Kromer, F. G. McCormac, S. W. Manning, R. W. Reimer, D. A. Richards, J. R. Southon, S. Talamo, C. S. M. Turney, J. van der Plicht, and C. E. Weyhenmeyer, IntCal09 and Marine09 Radiocarbon Age Calibration Curves, 0-50,000 Years cal BP, Radiocarbon, 51(4), 1111-1150, 2009.

Rhodes, B., M. Tuttle, B. Horton, L. Doner, H. Kelsey, A. Nelson, and M Cisternas, Paleotsunami research, Eos, 87(21), 205, 209, 2006.

Robinson, E., D.-A. C. Rowe, and S. A. Khan, Wave-emplaced boulders on Jamaica's Rocky Shores, Z. Geomorphol., Suppl. Vol., 146, 39-57, 2006

Scheffers, A., Tsunami imprints on the Leeward Netherlands Antilles (Aruba, Curaçao, Bonaire) and their relation to other coastal problems, Quatern. Int., 120, 163-172, 2004.

Scheffers, A., Coastal response to extreme wave events-hurricanes and tsunamis on Bonaire, Essen. Geogr. Arb., 37, 99 pp, 2005.

Scheffers, A. and S. Scheffers, Documentation of Hurricane Ivan on the Coastline of Bonaire, J. Coast. Res., 22(6), 1437-1450, 2006.

Scheffers, A., S. Scheffers, and D. Kelletat, Paleo-tsunami relics on the southern and central Antillean Island Arc, J. Coast. Res., 21(2), 263273, 2005.

Scheffers, S., J. Haviser, T. Browne, and A. Scheffers, Tsunamis, hurricanes, the demise of coral reefs and shifts in prehistoric human populations in the Caribbean, Quatern. Int., 195, 69-87, 2009.

Schubert, C. and S. Valastro, Quaternary geology of La Orchilla Island, central Venezuelan offshore, Caribbean Sea, Geol. Soc. Am. Bull., 87, 
1131-1142, 1976.

Spiske, M. and B. E. Jaffe, Sedimentology and hydrodynamic implications of a coarse-grained hurricane sequence in a carbonate reef setting, $\mathrm{Ge}$ ology, 37(9), 839-942, 2009.

Spiske, M., Z. Böröcz, and H. Bahlburg, The role of porosity in discriminating between tsunami and hurricane emplacement of boulders-A case study from the Lesser Antilles, southern Caribbean, Earth. Planet. Sci. Lett., 268, 384-396, 2008.

Sugawara, D., K. Minoura, and F. Imamura, Tsunamis and tsunami sedimentology, in Tsunamiites-Features and Implications, edited by $\mathrm{T}$. Shiki, Y. Tsuji, T. Yamazaki, and K. Minoura, pp. 9-49, Elsevier, Amsterdam, Oxford, 2008.

Switzer, A. D. and B. G. Jones, Large-scale washover sedimentation in a freshwater lagoon from the southeast Australian coast: Sea-level change, tsunami or exceptionally large storm?, Holocene, 18(5), 787803, 2008.

Szczuciński, W., The post-depositional changes of the onshore 2004 tsunami deposits on the Andaman Sea coast of Thailand, Nat. Haz., 60, 115-133, 2012.

ten Brink, U. S., E. L. Geist, and B. D. Andrews, Size distribution of submarine landslides and its implication to tsunami hazard in Puerto Rico, Geophys. Res. Lett., 33, L11307, 2006.

Uchida, J.-I., O. Fujiwara, S. Hasegawa, and T. Kamataki, Sources and depositional processes of tsunami deposits: Analysis using foraminiferal tests and hydrodynamic verification, Island Arc, 19, 427-442, 2010.

Wang, P. and M. H. Horwitz, Erosional and depositional characteristics of regional overwash deposits caused by multiple hurricanes, Sedimentology, 54, 545-564, 2007.

Ward, S. N. and S. Day, Cumbre Vieja Volcano-Potential collapse and tsunami at La Palma, Canary Islands, Geophys. Res. Lett., 28(17), 33974000, 2001.
Watt, S. G., B. E. Jaffe, R. A. Morton, B. M. Richmond, and G. Gelfenbaum, Description of extreme-wave deposits on the northern coast of Bonaire, Netherlands Antilles, USGS Open-File Report, 2010-1180, 64 pp., 2010.

Westermann, J. H. and J. I. S. Zonneveld, Photo-geological Observations and Land Capability \& Land Use Survey of the Island of Bonaire (Netherlands Antilles), 101 pp., Koninklijk Institut voor de Tropen, Amsterdam, 1956.

Woodroffe, C. D., Mangrove swamp stratigraphy and Holocene transgression, Grand Cayman Island, West Indies, Mar. Geol., 41, 271-294, 1981.

Woodroffe, C. D., Coasts, 623 pp., Cambridge University Press, Cambridge, 2002.

Yu, K.-F., J.-X. Zhao, Q. Shi, and Q.-S. Meng, Reconstruction of storm/tsunami records over the last 4000 years using transported coral blocks and lagoon sediments in the southern South China Sea, Quatern. Int., 195, 128-137, 2009.

Zahibo, N. and E. N. Pelinovsky, Evaluation of tsunami risk in the Lesser Antilles, Nat. Haz. Earth Syst., 1, 221-231, 2001.

Zonneveld, J. I. S., P. H. de Buisonjé, and J. P. Herweijer, Geomorphology and denudation processes, in Guide to the Field Excursions on Curaçao, Bonaire and Aruba, Netherlands Antilles (8th Caribbean Geological Conference, Curacao 9-24 July 1977), GUA Papers of Geology, 10, 5668, 1977.

M. Engel (e-mail: max.engel@uni-koeln.de), H. Brückner, K. Messenzehl, P. Frenzel, S. M. May, A. Scheffers, S. Scheffers, V. Wennrich, and D. Kelletat 